\title{
MESENCHYMAL STEM CELL SECRETOME DECREASES THE INFLAMMATORY RESPONSE IN ANNULUS FIBROSUS ORGAN CULTURES
}

\author{
C. Neidlinger-Wilke ${ }^{1, \$}$, A. Ekkerlein ${ }^{1, \$}$, R.M. Goncalves ${ }^{1,2,3,4}$, J.R. Ferreira ${ }^{2,3,4}$, A. Ignatius ${ }^{1}$, H.J. Wilke \\ and G.Q. Teixeira ${ }^{1, *}$ \\ ${ }^{1}$ Institute of Orthopaedic Research and Biomechanics, Trauma Research Centre, Ulm University, \\ Ulm, Germany \\ ${ }^{2}$ Instituto de Investigação e Inovação em Saúde (i3S), Universidade do Porto, Porto, Portugal \\ ${ }^{3}$ Instituto de Engenharia Biomédica (INEB), Universidade do Porto, Porto, Portugal \\ ${ }^{4}$ Instituto de Ciências Biomédicas Abel Salazar (ICBAS), Universidade do Porto, Porto, Portugal \\ $\S$ These authors contributed equally to this work
}

\begin{abstract}
Mesenchymal stem/stromal cell (MSC)-based therapies have been proposed for back pain and disc degeneration, despite limited knowledge on their mechanism of action. The impact of MSCs/their secretome on annulus fibrosus (AF) cells and tissue was analysed in bovine AF organ cultures (AF-OCs) exposed to upper-physiological cyclic tensile strain (CTS, $9 \%, 1 \mathrm{~Hz}, 3 \mathrm{~h} / \mathrm{d}$ ) and interleukin (IL)-1 $\beta$ in a custom-made device. A $4 \mathrm{~d}$ treatment of the CTS + IL-1 $\beta$-stimulated AF-OCs with MSC secretome downregulated the expression of inflammation markers [IL-6, IL-8, prostaglandin-endoperoxide synthase 2 (PTGS2)], complement system regulators [cluster of differentiation (CD)46, CD55, CD59] and matrix metalloproteinase 1 but also of tissue inhibitors of metalloproteinases (TIMP-1, TIMP-2) and collagen type I. At the protein level, it was confirmed that IL-6, MMP-3 and collagen content was decreased in AF-OCs treated with the MSC secretome compared to the CTS + IL-1 $\beta$ stimulation alone. $9 \mathrm{~d}$ after treatment, a biomechanical peel-force test showed that the annular adhesive strength was significantly decreased by the MSC secretome treatment. Overall, MSC secretome had a stronger impact on AF tissue than MSCs in co-culture. The secretome contributed to a decrease in the inflammatory and catabolic status of AF cells activated by CTS + IL-1 $\beta$ and played a role in the regulation of the complement system. However, it also contributed to a decrease in collagen at the gene/protein level and in AF mechanical strength compared to the CTS + IL-1 $\beta$ stimulation alone. Therefore, the use of MSC secretome requires further investigation regarding its influence on disc matrix properties.
\end{abstract}

Keywords: Intervertebral disc, degeneration, herniation, repair/regeneration, mechanical loading, inflammation, complement, paracrine signalling.

*Address for correspondence: Dr Graciosa Quelhas Teixeira, Institute of Orthopaedic Research and Biomechanics, Trauma Research Centre, Ulm University, Helmholtzstraße 14, 89081 Ulm, Germany.

Telephone number: +49 73150055324 Email: graciosa.teixeira@uni-ulm.de

Copyright policy: This article is distributed in accordance with Creative Commons Attribution Licence (http://creativecommons.org/licenses/by-sa/4.0/).

\begin{tabular}{|c|c|c|c|}
\hline & List of Abbreviations & $\begin{array}{l}\text { COL1A1 } \\
\text { COL2 }\end{array}$ & $\begin{array}{l}\text { collagen type I alpha } 1 \text { chain } \\
\text { collagen type II }\end{array}$ \\
\hline $\mathrm{b}$ & bovine gene & COX-2 & cyclooxygenase- 2 \\
\hline $\mathrm{h}$ & human gene & CTS & cyclic tensile strain \\
\hline ACAN & aggrecan & DMEM & Dulbecco's modified Eagle medium \\
\hline ADAMTS & $\begin{array}{l}\text { a disintegrin and metalloproteinase } \\
\text { with thrombospondin motifs }\end{array}$ & ELISA & $\begin{array}{l}\text { enzyme-linked immunosorbent } \\
\text { assay }\end{array}$ \\
\hline $\mathrm{AF}$ & annulus fibrosus & GAPDH & glyceraldehyde 3-phosphate \\
\hline AF-OC & AF organ culture & & dehydrogenase \\
\hline CCL & chemokine (C-C motif) ligand 2 & IL & interleukin \\
\hline CD & cluster of differentiation & IL-1ra & IL-1 receptor antagonist \\
\hline CFH & complement factor $\mathrm{H}$ & IVD & intervertebral disc \\
\hline
\end{tabular}




$\begin{array}{ll}\text { LM } & \text { lamella matrix } \\ \text { NOS2 } & \text { nitric oxide synthase 2 } \\ \text { MMP } & \text { matrix metalloproteinase } \\ \text { MSC } & \text { mesenchymal stem/stromal cells } \\ \text { NP } & \text { nucleus pulposus } \\ \text { PGE } & \text { prostaglandin } \text { E }_{2} \\ \text { PTGS2 } & \text { prostaglandin-endoperoxide } \\ & \text { synthase } 2 \\ \text { sGAG } & \text { sulphated glycosaminoglycan } \\ \text { TCC } & \text { terminal complement complex } \\ \text { TIMP } & \text { tissue inhibitors of MMPs } \\ \text { TLBN } & \text { translamellar bridging network } \\ \text { VEGF } & \text { vascular endothelial growth factor }\end{array}$

\section{Introduction}

IVD degeneration and related inflammation are frequently associated with back, neck and radicular pain, major causes of disability globally representing a significant economic burden (Moradi-Lakeh et al., 2017; Murray et al., 2015). Current treatments ranging from physiotherapy to invasive surgeries, including spine fusion and IVD replacement, may decrease the symptoms' progression but fail to restore the native IVD properties. Therefore, there is an urgent need to develop therapies supporting IVD regeneration.

While IVD degeneration is normally associated with ageing (Roberts et al., 2006), cases of early degeneration are also frequently observed. The degenerative IVD pathogenesis may be caused by genetic predisposition, injury and/or lifestyle among others. Disc degeneration involves the interplay between several mechanisms, including mechanical overloading, catabolic cell response, degradation of matrix proteoglycans and loss of water-binding capacity (Adams and Roughley, 2006; Vergroesen et al., 2015), as well as cell senescence and apoptosis (Roberts et al., 2006). These events are frequently associated with an immune response, which plays an important role in the pathogenesis of IVD degeneration and cell death. During these events, the production of extracellular-matrix-degrading enzymes (MMP-1, $-3,-13$, ADAMTS-4, $-5,-13$, etc.), proinflammatory mediators (IL-1 $\beta,-6,-8$, tumour necrosis factor- $\alpha$, etc.) and chemoattractants of immune cells (CCL2, CCL5) has been identified (Molinos et al., 2015; Risbud and Shapiro, 2014). Complement-mediated processes are known coordinators of several events during inflammation and significantly contribute to inflammation-mediated tissue damage (Ricklin and Lambris, 2013). Upon activation, complement proteins function as chemotactic factors and amplifiers of the inflammatory response (Ricklin and Lambris, 2013). The activation of TCC formation - a complement system activation product that acts as an inflammatory trigger and induces cell lysis - was shown to be abnormally high in human osteoarthritic joints (Wang et al., 2011) and degenerated IVDs, with a predominance in AF cells (Grönblad et al., 2003). However, little is known about complement system regulation by IVD cells through the production of soluble CFH or the expression of membrane-bound regulators, including membrane cofactor protein (CD46), complement decay-accelerating factor (CD55) and protectin (CD59), which inhibits TCC formation and confers protection from complementmediated lysis (Noris and Remuzzi, 2013).

The AF consists of concentric lamellae of regularly arranged collagen fibres, which are interconnected by a network of elastin and fibrillin (Yu et al., 2015). The pathomechanism leading to reduced mechanical function is under-investigated; however, the progressive structural weakening of the IVD may contribute to AF failure and tissue herniation (Adams and Roughley, 2006). There is pertinent clinical relevance for a cost-effective, minimally invasive therapeutic approaches to modulate the immune response and ultimately delay or reverse degeneration before AF tear. In recent years, gene-, cell- or molecular-based therapies have been proposed for patients with painful IVDs at early stages of degeneration (Pfirrmann grades III-IV).

Despite the limited regenerative potential of the degenerated AF, it has been hypothesised to benefit from the presence of cells capable of proliferating and differentiating into AF-like cells. Although progenitor cells have been found in the human IVD, their number decreases very rapidly after birth (Sakai et al., 2012), limiting the IVD's potential to counteract degeneration or recover from an injury. Therefore, cell-based therapies to stimulate IVD regeneration, namely those using bone-marrow-derived MSC, are being increasingly pursued. MSC transplantation potential has been shown to be associated with their ability to differentiate into IVD-like cells, producing IVD matrix components or promoting the stimulation of endogenous IVD cells, thus enabling anti-catabolic and anti-inflammatory effects, as reviewed by Sakai and Anderson (2015). Patients have reported reduced pain in clinical trials after MSC transplantation; however, either no changes in disc morphology or water-binding capacity or only a minor Pfirrmann grading improvement were observed (Noriega et al., 2017; Orozco et al., 2011; Yoshikawa et al., 2010). MSCs secrete anti-inflammatory factors and influence matrix turnover in short-term osteoarthritic synovium and cartilage explant cultures (van Buul et al., 2012). Pereira et al. (2016) showed that MSCs seeded on cartilaginous endplates significantly increase the production of growth factors, as well as of COL2 and ACAN in the NP. Cunha et al. (2017) observed in a rat disc herniation model less degeneration/herniation in the MSC-transplanted group. Although no significant changes were detected in the extracellular matrix composition, the transplanted MSCs appeared to modulate the immune response towards tissue regeneration (Cunha et al., 2017). A previous study showed that MSCs in co-culture with a proinflammatory/degenerative NP organ culture can modulate the proinflammatory profile of the NP cells, while themselves displaying a proinflammatory 
profile (Teixeira et al., 2018). However, because very few MSCs have been found in the IVD tissue, the authors hypothesised that their paracrine effect via the secretome might have a larger effect on IVD cells than direct contact. MSCs secrete numerous soluble factors in response to microenvironmental cues, regulating several mechanisms in neighbouring tissues via paracrine signalling (Brisby et al., 2013). Accordingly, several studies have suggested the use of MSC secretome for cardiac tissue repair (Dai et al., 2007) and the recovery of hepatic (Parekkadan et al., 2007) and kidney (van Koppen et al., 2012) functions, among others. Moreover, MSC secretome was suggested to stimulate IVD progenitor cell activity ex vivo in degenerated human IVD tissue samples towards the repair process (Brisby et al., 2013).

Preconditioning (or priming) of MSCs ex vivo by a low oxygen atmosphere and inflammatory stimulus, including IL-1 $\beta$ (Fan et al., 2012), among others, prior to their use in therapy is recognised as an adaptive strategy that tunes the cells to survive in harsh microenvironments and enhances their regulatory control of the innate and adaptive immune responses (Ferreira et al., 2018; Saparov et al., 2016). MSC-mediated immunomodulation has mainly been attributed to paracrine mechanisms associated with the secretion of proinflammatory/immunoregulatory mediators (Krampera et al., 2006; Ren et al., 2008). Nonetheless, the presence of different concentrations of proinflammatory molecules may differently influence their immunomodulatory response ( $\mathrm{Li}$ et al., 2012), suggesting that their secretome may lead to a more reproducible outcome.

The aims of the present study were to investigate the anti-inflammatory and regenerative effects of i) MSC application or ii) MSC secretome application on a proinflammatory AF-OC model. In this context, the following hypotheses were investigated: i) the proinflammatory environment led to complement system activation and changes in the AF cell phenotype; ii) MSC secretome was more effective in comparison to MSC transplantation to induce immune-mediated changes of AF tissue integrity.

\section{Materials and Methods}

\section{MSC expansion and secretome production}

Normal bone-marrow-derived MSCs (PT-2501, Lonza) were isolated from bilateral punctures of the posterior iliac crests of human donors $(n=3$, one female/two males, mean age $=23.3$ years). Donor information is summarised in Table 3. MSCs were seeded at a density of 3,000 cells $/ \mathrm{cm}^{2}$ and routinely expanded in MSC medium composed of low-glucose DMEM (21885-108, Gibco) supplemented with $10 \%$ HyClone calf serum (SH30073.03, GE Healthcare), $1 \%$ penicillin-streptomycin $(10,000 \mathrm{U} / \mathrm{mL}$ penicillin and $10,000 \mu \mathrm{g} / \mathrm{mL}$ streptomycin, 15140-122, Gibco) and $0.5 \%$ amphotericin B $(250 \mu \mathrm{g} / \mathrm{mL}, 15290-026$, Gibco) at $37^{\circ} \mathrm{C}$ under a humidified atmosphere with $8.5 \% \mathrm{CO}_{2}$. The medium was exchanged twice a week and cells were trypsinised when reaching $70 \%$ confluency.

For the secretome production, $10^{6} \mathrm{MSCs}$ were seeded in 6-well plates (657160, Greiner) and incubated for $2 \mathrm{~d}$ in $5 \mathrm{~mL}$ MSC medium supplemented with $10 \mathrm{ng} / \mathrm{mL}$ recombinant human IL-1 $\beta$ (201-LB, R\&D Systems) at $37^{\circ} \mathrm{C}$ in a humidified atmosphere containing $6 \% \mathrm{O}_{2}$ and $8.5 \% \mathrm{CO}_{2}$ (Fig. 1a). Subsequently, the secretome was collected and centrifuged at $1,800 \times \mathrm{g}$ for $5 \mathrm{~min}$ at $4{ }^{\circ} \mathrm{C}$ to remove cell debris and then stored at $-80{ }^{\circ} \mathrm{C}$ until further use. Cells maintained under basal conditions were also collected for gene expression analysis prior to co-culture with AF-OCs. MSCs in passages 4-9 were used for the experiments.

\section{Tissue dissection and organ culture preparation} AF-OCs were prepared according to Saggese et al. (2019). Bovine tails from 12-24-month-old animals $(n=20)$ were obtained from a local slaughterhouse (Fleischmarkt Donautal, Ulm, Germany) and dissected within $2 \mathrm{~h}$ after euthanasia. Coccygeal segments 2-3 to 7-8 were isolated and the NP was removed using 14-16 $\mathrm{mm}$ diameter punches, depending on the IVD size. The collected AF rings were incubated at $37^{\circ} \mathrm{C}$ in a humidified atmosphere of $6 \% \mathrm{O}_{2}$ and $8.5 \% \mathrm{CO}_{2}$ in IVD medium composed of low-glucose DMEM supplemented with $5 \%$ FBS Superior (S0615, Biochrom), $1 \%$ non-essential amino acids (11140-035, Gibco), $1 \%$ penicillinstreptomycin, $0.5 \%$ amphotericin B and $1.5 \% 5 \mathrm{~mol} / \mathrm{L}$ $\mathrm{NaCl} / 0.4 \mathrm{~mol} / \mathrm{L} \mathrm{KCl}$ solution to adjust the osmolarity to $400 \mathrm{mOsm}$, as previously described (NeidlingerWilke et al., 2012; Teixeira et al., 2016). The rings were left for $6 \mathrm{~d}$ in six-well plates with membrane filter inserts (MCEP06H48, Millipore) and 0.46 MPa static loading (Teixeira et al., 2016). The medium was exchanged every second day.

\section{Treatment of AF rings with MSCs and MSC secretome}

On day 6, the AF-OCs were transferred to silicone dishes and placed in a CTS device, as previously established (Saggese et al., 2019). The experimental timeline and groups are depicted in Fig. $1 \mathbf{b}$.

For the AF-OCs treated with MSC co-culture, $10^{6}$ MSCs were seeded on top of the AF rings in the CTS device and left for $24 \mathrm{~h}$ to adhere. MSCs were expanded as described above in the "MSC expansion and secretome production" section but not preconditioned with inflammation factors. On the next day, the medium was exchanged in all experimental groups according to Table 1 . AF-OCs were stimulated with CTS at $1 \mathrm{~Hz}, 3 \mathrm{~h} / \mathrm{d}$. The CTS generated a $9 \pm 3 \%$ tensile stress of the AF-OC rings, representing a high physiological loading (Saggese et al., 2019). One group was stimulated with CTS + IL-1 $\beta$ alone, while an additional group was stimulated with CTS + IL-1 $\beta$ and MSCs were co-cultured on top of the AF rings. A third group was stimulated with CTS + IL-1 $\beta$ and 
the culture medium was mixed with $5 \mathrm{~mL}$ MSC secretome produced by $0.2 \times 10^{6} \mathrm{MSCs} / \mathrm{mL}$. The MSC secretome was mixed in a $1: 1$ ratio with IVD medium ( $5 \mathrm{~mL}$ MSC secretome $+5 \mathrm{~mL}$ IVD medium) supplemented with $10 \mathrm{ng} / \mathrm{mL}$ IL-1 $\beta$. Unstimulated AF rings were defined as the control group.

At day 11, samples were collected for different analyses. The AF rings were separated into three sections: the tissue was either i) immediately shockfrozen in RNAlater ICE (AM7030, Invitrogen) and liquid nitrogen and stored at $-80^{\circ} \mathrm{C}$ for RNA isolation, ii) weighed (tissues with weight between 70 and $130 \mathrm{mg}$ were collected) and frozen at $-20^{\circ} \mathrm{C}$ for DNA and protein quantification or iii) used for metabolic activity quantification and subsequently fixed in $4 \%$ phosphate-buffered formaldehyde solution ( $\mathrm{pH} 7.4$ ) for immunohistochemical staining.
For the AF-OCs that underwent treatment for $9 \mathrm{~d}, 50 \%$ of the medium was exchanged at day 11 according to Table 1 . At day 16, the AF rings were collected for metabolic activity quantification and mechanical testing. The supernatants were collected for protein quantification.

Metabolic activity of AF cells in organ culture The metabolic activity of AF cells was assessed using the resazurin reduction assay. AF tissue sections of $70-130 \mathrm{mg}$ wet weight were incubated with $0.02 \mathrm{mg} /$ $\mathrm{mL}$ resazurin sodium salt (R7017, Sigma-Aldrich) solution in IVD medium for $2 \mathrm{~h}$ at $37^{\circ} \mathrm{C}$. Fluorescence intensity was determined using a spectrophotometer microplate reader (Spark, Tecan), with $530 \mathrm{~nm}$ excitation filters and $590 \mathrm{~nm}$ emission filters. Results were normalised to the wet weight $(\mathrm{mg})$ for each

a

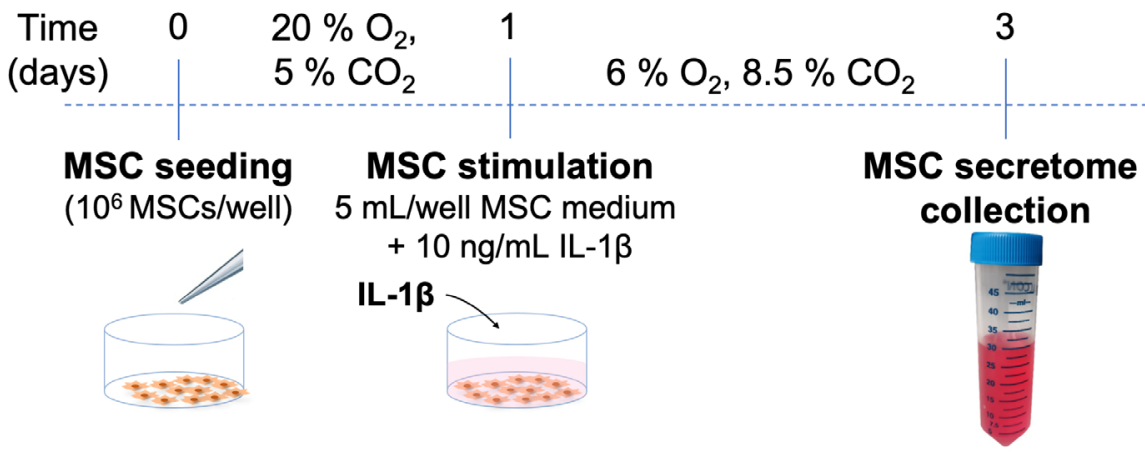

b

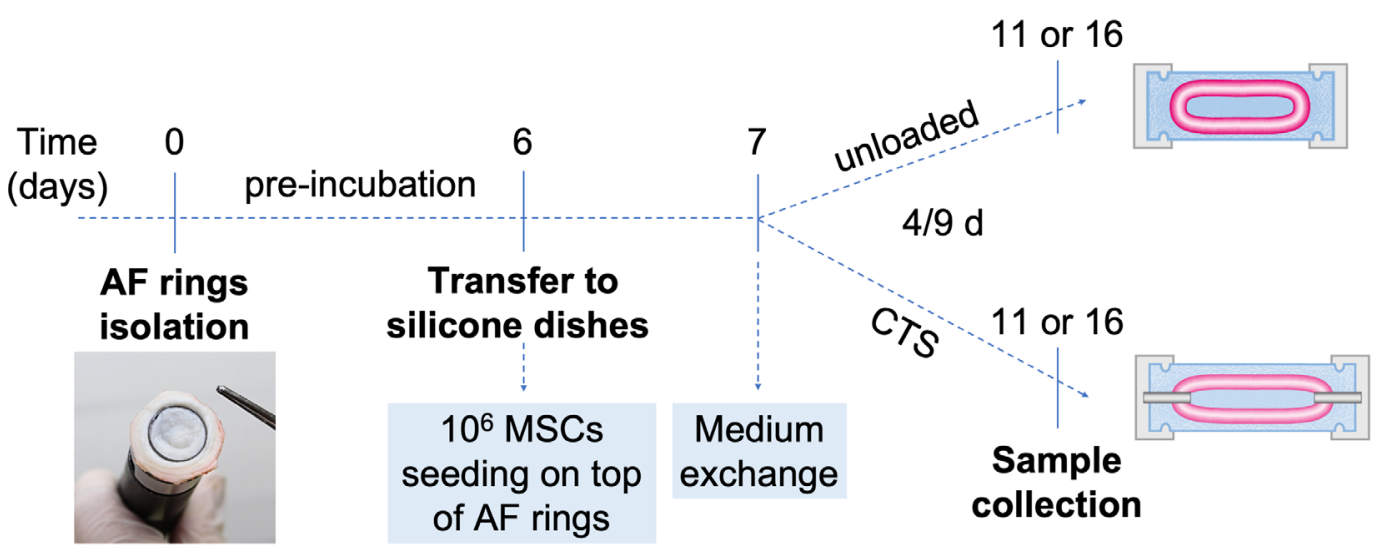

Experimental groups from day 7 on

\begin{tabular}{|c|c|c|c|}
\hline Group & CTS + IL-1 $\beta$ & MSC & MSC secretome \\
\hline Control & - & - & - \\
\hline CTS + IL-1 $\beta$ & + & - & - \\
\hline MSC & + & + & - \\
\hline Secretome & + & - & + \\
\hline
\end{tabular}

\section{Sample collection}

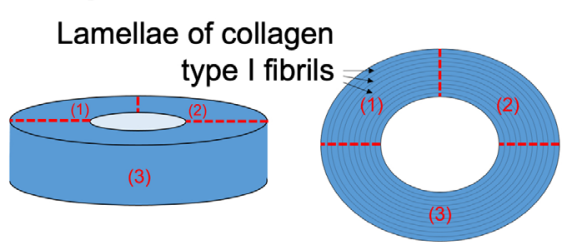

Fig. 1. Experimental timeline and experimental groups. (a) MSC secretome was produced by $10^{6}$ MSCs preconditioned with $10 \mathrm{ng} / \mathrm{mL}$ IL-1 $\beta$ medium supplementation and culture at $37{ }^{\circ} \mathrm{C}$ under $6 \% \mathrm{O}_{2}$ and

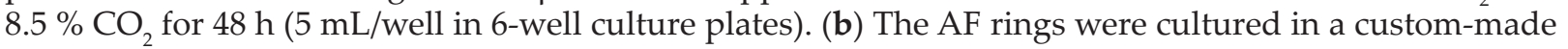
electromechanical device for the application of CTS to deformable silicone dishes and with IL-1 $\beta$ in the culture medium. The stimulated AF-OCs were either treated with MSCs in co-culture or MSC secretome. 
Table 1. Media added at days 7 and 11 of culture to the different experimental groups.

\begin{tabular}{|c|c|}
\hline Group & Medium \\
\hline Control & IVD medium \\
\hline CTS + IL-1 $\beta$ & IVD medium $+10 \mathrm{ng} / \mathrm{mL} \mathrm{IL-1} \beta$ \\
\hline MSC & IVD medium $+10 \mathrm{ng} / \mathrm{mL} \mathrm{IL-1} \beta$ \\
\hline Secretome & IVD medium + MSC secretome $(1: 1 \mathrm{ratio})+10 \mathrm{ng} / \mathrm{mL}$ IL-1 $\beta$ \\
\hline
\end{tabular}

Table 2. Bovine oligonucleotide primers used for qRT-PCR. Primers with shown sequence were custom designed; primers with assay ID number were purchased from Applied Biosystems. fw: forward; rev: reverse; b: bovine.

\begin{tabular}{|c|c|c|}
\hline Gene & Sequence (forward and reverse primer) & Product size (bp) \\
\hline bACAN & $\begin{array}{l}\text { fw: 5'-ACA GCG CCT ACC AAG ACA AG-3' } \\
\text { rev: 5'-ACG ATG CCT TTT ACC ACG AC- } 3^{\prime}\end{array}$ & 155 \\
\hline bADAMTS-4 & $\begin{array}{l}\text { fw: 5'-GAA GCA ATG CAC TGG TCT GA-3' } \\
\text { rev: 5'-CTA GGA GAC AGT GCC CGA AG-3' }\end{array}$ & 155 \\
\hline$b C D 46$ & assay ID: Bt03224806_m1 & 97 \\
\hline$b C D 55$ & assay ID: Bt03220649_m1 & 67 \\
\hline$b C D 59$ & assay ID: Bt03229098_m1 & 135 \\
\hline$b$ COL1A1 & assay ID: Bt01463861_g1 & 61 \\
\hline$b G A P D H$ & $\begin{array}{l}\text { fw: 5'-ACC CAG AAG ACT GTG GAT GG-3' } \\
\text { rev: 5'-CAA CAG ACA CGT TGG GAG TG-3' }\end{array}$ & 178 \\
\hline bIL-6 & $\begin{array}{l}\text { fw: 5'-ACC CCA GGC AGA CTA CTT CT-3' } \\
\text { rev: 5'-GCA TCC GTC CTT TTC CTC CA-3' }\end{array}$ & 183 \\
\hline bIL-8 & $\begin{array}{l}\text { fw: 5'-ATT CCA CAC CTT TCC ACC CC-3' } \\
\text { rev: 5'-ACA ACC TTC TGC ACC CAC TT-3' }\end{array}$ & 148 \\
\hline$b M M P-1$ & $\begin{array}{l}\text { fw: 5'-ATG CTG TTT TCC AGA AAG GTG G-3' } \\
\text { rev: 5'-TCA GGA AAC ACC TTC CAC AGA C-3' }\end{array}$ & 193 \\
\hline$b M M P-3$ & assay ID: Bt04259490_m1 & 76 \\
\hline$b N O S 2$ & assay ID: Bt03249602_g1 & 56 \\
\hline bPTGS2 & assay ID: Bt03214492_m1 & 87 \\
\hline bTIMP-1 & assay ID: Bt03223721_m1 & 57 \\
\hline bTIMP-2 & assay ID: Bt03231007_m1 & 88 \\
\hline$b V E G F$ & $\begin{array}{l}\text { fw: 5'-TTG CCT TGC TGC TCT ACC TT-3' } \\
\text { rev: 5'-ACA CAG GAC GGC TTG AAA AT-3' }\end{array}$ & 196 \\
\hline
\end{tabular}

Table 3. Human MSC donor information.

\begin{tabular}{|c|c|c|}
\hline MSC donor & Age (years old) & Gender \\
\hline $\mathbf{1}$ & 25 & female \\
\hline $\mathbf{2}$ & 23 & male \\
\hline $\mathbf{3}$ & 22 & male \\
\hline
\end{tabular}

AF tissue. The AF tissues were frozen at $-20{ }^{\circ} \mathrm{C}$ for protein quantification.

\section{Gene expression analysis of AF cells}

Tissues frozen in RNAlater ICE were thawed, RNAlater was removed and $1 \mathrm{~mL}$ TRIzol was added to the tissue to maintain the RNA integrity during tissue homogenisation performed using a dismembrator (D-9, Miccra GmbH, Heitersheim, Germany). Subsequently, $200 \mu \mathrm{L}$ of chloroform were added to perform a two-phase extraction of the RNA. Following a 5 min incubation step, the mixture was centrifuged for $30 \mathrm{~min}$ at $14,000 \times g$ and $4{ }^{\circ} \mathrm{C}$. RNA was collected and transferred to an RNAse-free reaction tube. By adding an equivalent volume of $70 \% \mathrm{EtOH}$, the RNA was precipitated. RNA isolation was performed using the PicoPure RNA Isolation kit (KIT0204, Thermo Fisher Scientific). For cDNA synthesis with integrated removal of DNA contamination, $12 \mu \mathrm{L}$ RNA were treated using the QuantiTect Reverse Transcription kit (205313, Qiagen). Gene expression analysis was performed using primers for the reference gene $b G A P D H$, as well as for the target genes (Table 2). The transcribed cDNA 
was either mixed with custom-designed primers and Platinum SYBR Green qPCR SuperMix-UDG kit (11733-038, Invitrogen) or TaqMan Gene Expression Assays and Fast Advanced Master Mix (4444557, Applied Biosystems). Runs were performed using the QuantStudio 3 real-time PCR system (Applied Biosystems). Melting curves were analysed to confirm the specificity of the reaction and the quantification cycle 35 was used as cut-off. Relative expression levels were calculated by the Livak method (using the $2^{-\Delta \Delta C t}$ method), being $\Delta \Delta \mathrm{Ct}=\Delta \mathrm{Ct}_{\text {(sample of interest) }}-\Delta \mathrm{Ct}_{\text {(contro }}$ sample), where $\Delta \mathrm{Ct}=\mathrm{C} \mathrm{t}_{\text {(gene of interest) }}-\mathrm{Ct}_{(\text {GAPDH) }}$ (Livak and Schmittgen, 2001).

\section{Protein quantification in the organ culture supernatants}

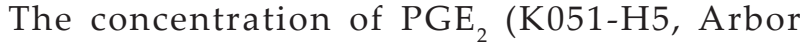
Assays, Ann Arbor, MI, USA), bIL-6 (MBS9141101, MyBioSource San Diego, CA, USA), hIL-6 (430507, BioLegend), hIL-1 $\beta$ (DLB50, R\&D Systems), hIL1ra (BRA00B, R\&D Systems), hCFH (ab137975, Abcam), hTIMP-1 (ELH-TIMP1, RayBiotech, Peachtree Corners, GA, USA) and hTIMP-2 (ELHTIMP2, RayBiotech) was determined by ELISA in the supernatants at days 11 and 16 of organ culture.

\section{DNA and protein quantification in the AF tissue}

AF tissues were digested overnight at $56{ }^{\circ} \mathrm{C}$ using $0.5 \mathrm{mg} / \mathrm{mL}$ proteinase K (P6556, SigmaAldrich) solution for DNA and sGAG quantification. DNA content was determined using the Quant-iT PicoGreen dsDNA assay kit (P7589, Invitrogen). sGAG content was determined using the Blyscan assay kit (B1000, Biocolor, Carrickfergus, UK). AF tissues were digested for soluble collagen and elastin quantification according to the Sircol (S1000, Biocolor) and Fastin (F2000, Biocolor) assay kits, respectively.

\section{Immunohistochemistry}

Following fixation in formalin for $48 \mathrm{~h}$, AF samples were washed under running tap water for $2 \mathrm{~h}$, dehydrated and embedded in paraffin-wax. Crosssections with $7 \mu \mathrm{m}$ thickness were dewaxed and rehydrated. For antigen retrieval, the sections were incubated with $10 \mathrm{mmol} / \mathrm{L}$ citrate buffer $(\mathrm{pH} \mathrm{6.0,}$ $\left.85^{\circ} \mathrm{C}, 20 \mathrm{~min}\right)$, followed by hyaluronidase $(2 \mathrm{mg} /$ $\mathrm{mL}$ in citrate buffer, $\mathrm{pH} 8.0,30 \mathrm{~min}, 37^{\circ} \mathrm{C}$ ) and collagenase $(2 \mathrm{mg} / \mathrm{mL}$ in citrate buffer, $\mathrm{pH} 8.0,15 \mathrm{~min}$, $37^{\circ} \mathrm{C}$ ) digestion. The avidin-biotin complex kit (PK6100 , Vector laboratories) and Vector ${ }^{\circledR}$ NovaRED $^{\circledR}$ Substrate Kit, Peroxidase (HRP) (SK-4800, Vector Laboratories) were used for the immunostaining. Sections were incubated with rabbit anti-IL-6 (1 : 200, bs0782R, Bioss, Woburn, MA, USA) or rabbit antiMMP3 (1:200, ab15191, Abcam) antibodies overnight at $4{ }^{\circ} \mathrm{C}$, according to Saggese et al. (2019). Goat antirabbit IgG Biotin-XX (1 : 200, B-2770, Invitrogen) was used as secondary antibody. Primary antibodies were polyclonal and reacted with human and bovine molecules. All samples from the same experiment were stained at the same time for each marker for comparison purposes.

\section{Microscopy and image analysis}

From each of the IL-6- and MMP-3-stained sections, images were obtained from three different areas. For each area, images were acquired by bright-field and polarised-light microscopy. Polarised-light images were used to distinguish the birefringent LM from the black TLBN regions. To evaluate each staining, the bright-field images were processed using ImageJ software and the colour deconvolution function to separate the Vector ${ }^{\circledR}$ NovaRED $^{\circledR}$ and haematoxylin colour components. Subsequently, the TLBN and the LM were outlined in the Vector $^{\circledR}$ NovaRED $^{\circledR}$ colour channel as regions of interest and the mean pixel intensity was measured for each region. The TLBN/ LM ratio of the colour intensities was calculated and the mean of the three images was used to normalise the values of each sample to the control sample from the same experiment. For each experiment $(n=7-10)$ all samples were stained at the same time.

\section{Mechanical testing}

A peel test was performed to determine the peeling strength of the AF, according to Gregory et al. (2012). AF segments were incised along a central lamella by $5 \mathrm{~mm}$ into a " $\mathrm{Y}$ " configuration. The split ends of the specimens were fixed in a " $\mathrm{T}$ " configuration in a uniaxial material testing machine (Z10, Zwick). The adjacent lamellae were pulled apart at $0.5 \mathrm{~mm} / \mathrm{s}$ until the complete separation of the tissue. The mean force in the plateau regions of each force-displacement curve was normalised to the height of the AF tissue and used to calculate the delamination strength (Gregory et al., 2012; Saggese et al., 2019)

\section{Statistical analysis}

Results are presented as median \pm interquartile range. Statistical analysis was performed using GraphPad Prism 8 software (GraphPad Software, Inc.). Data were tested for normal distribution using D'Agostino-Pearson omnibus normality test. Parametric data were analysed using unpaired $t$-test to determine differences between two groups or oneway analysis of variance to determine differences between three or more groups. Nonparametric data were analysed using Kruskal-Wallis test with Dunn's multiple comparison test to determine differences between three or more groups. Significance was set at $p<0.05$.

\section{Results}

Analysis of cell viability and gene expression profile of AF cells

To induce a degenerative and proinflammatory environment, AF-OCs were stimulated day 7 after isolation with CTS + IL-1 $\beta$. The rings were either 


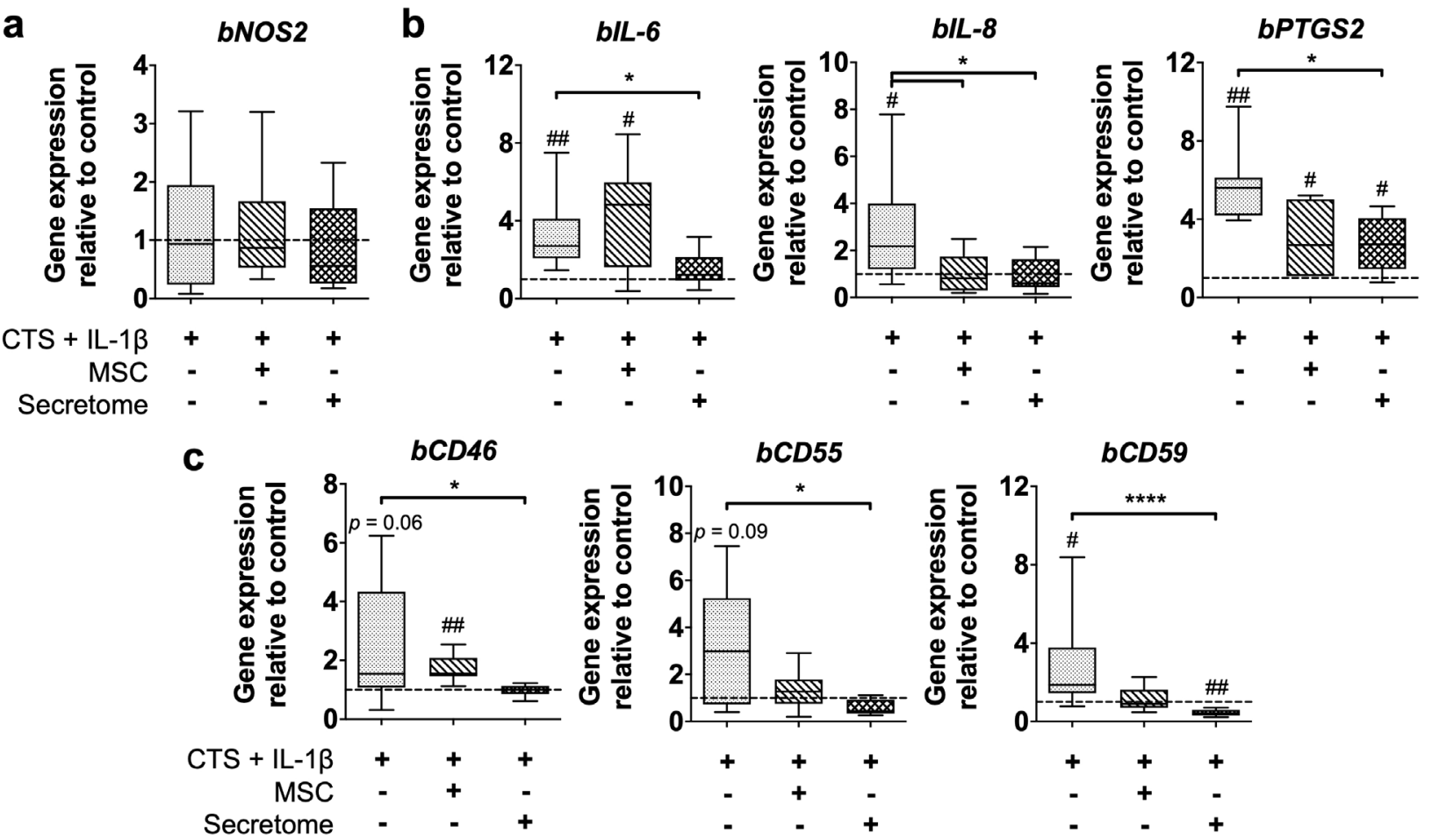

Fig. 2. Gene expression of bovine AF cells at day 11 of organ culture. (a) Relative mRNA expression of bovine cell survival marker $b N O S 2$, (b) proinflammatory markers and (c) complement regulators. Results were normalised to the expression level of $b G A P D H$ and control group (dashed line $=1) \cdot n=5-12(5-12$ IVD biological replicates; 3 MSC biological replicates and 1-4 experimental replicates); ${ }^{\#} p<0.05,{ }^{\# \#} p<0.01$ (versus control); ${ }^{*} p<0.05,{ }^{* * * *} p<0.0001$ (between CTS + IL-1 $\beta$ stimulation and treatments).

a
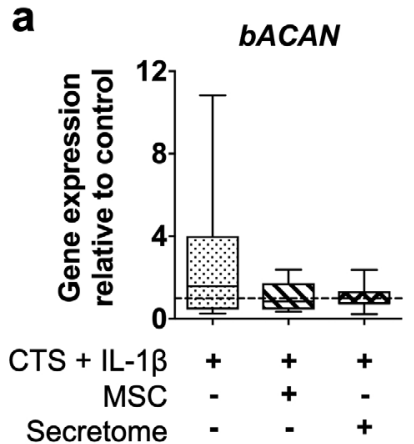

C
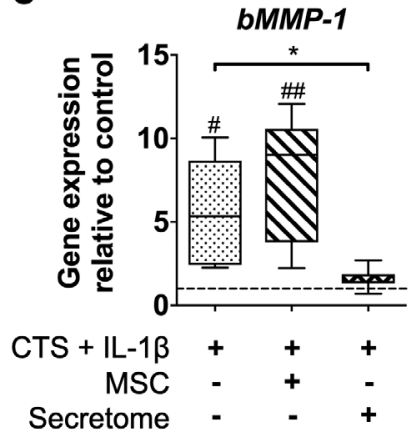

bCOL1A1
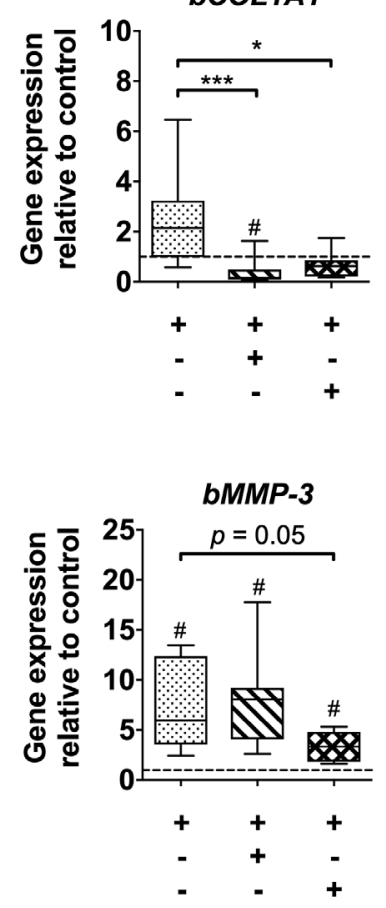

b
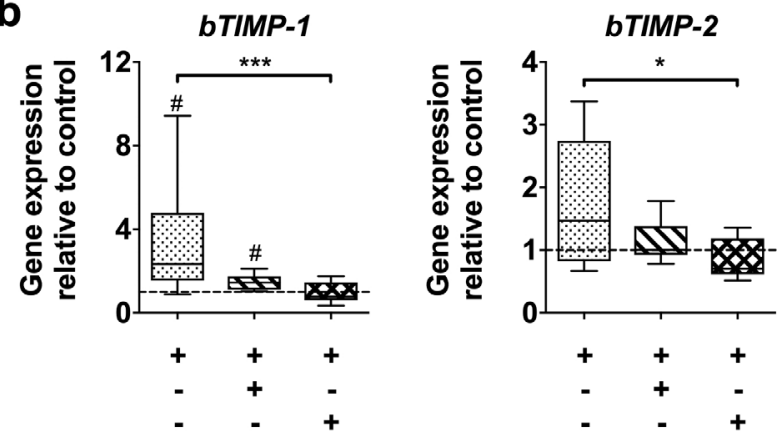

d

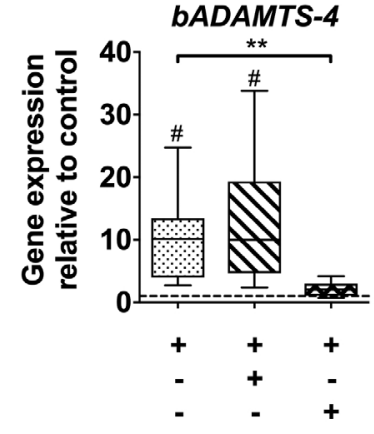

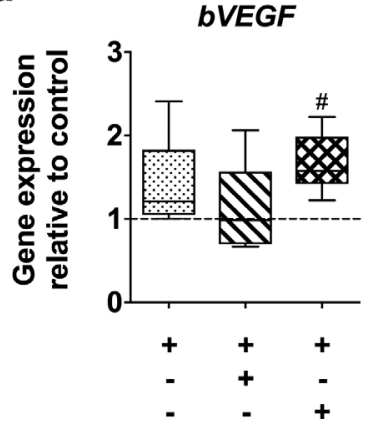

Fig. 3. Gene expression of bovine AF cells at day 11 of organ culture. (a) Relative mRNA expression of bovine matrix components, (b) TIMPs, (c) matrix degrading enzymes and (d) vascularisation marker $b V E G F$. Results were normalised to the expression level of $b G A P D H$ and control group (dashed line =1). $n=6-12$ (612 IVD biological replicates; 3 MSC biological replicates and 2-4 experimental replicates); ${ }^{\sharp} p<0.05,{ }^{\# \#} p<0.01$ (versus control); ${ }^{*} p<0.05,{ }^{* *} p<0.01,{ }^{* * *} p<0.001$ (between CTS + IL-1 $\beta$ stimulation and treatments). 
treated with MSCs (MSC group) or secretome of pre-conditioned MSCs (secretome group) to mimic the physiological conditions of MSCs in the AF-OC model.

To investigate whether AF cell viability was affected by CTS + IL-1 $\beta$, co-culture with MSCs or secretome treatment after $4 \mathrm{~d}$ of organ culture, the expression of bNOS2, a marker of cell survival, was analysed (Fig. 2a). No differences were observed between the experimental groups. The proinflammatory markers bIL-6, bIL-8 and bPTGS2 were significantly upregulated in the CTS + IL-1 $\beta$ treated group $(p<0.05)$ in comparison to the control group and to the combination with the secretome treatment $(p<0.05$, Fig. $2 \mathbf{b})$. The MSC group presented upregulated bIL-6 and bPTGS2 expression in comparison to the control group $(p<0.05)$ and upregulated $b I L-8$ expression versus CTS + IL-1 $\beta$ stimulation alone $(p<0.05)$. Regarding the expression of inhibitory complement receptors (Fig. 2c), bCD46, $b C D 55$, and $b C D 59$ were upregulated after CTS + IL$1 \beta$ stimulation when compared to control samples, this being statistically significant for $b$ CD59 $(p<0.05)$. The secretome treatment significantly downregulated $b C D 46, b C D 55$ (both $p<0.05)$ and bCD59 $(p<0.0001)$ expression in comparison to CTS + IL- $1 \beta$ stimulation alone. $b C D 46$ was upregulated in the MSC-treated group, whereas $b C D 59$ was downregulated in secretome-treated samples, both in comparison to the control group $(p<0.01)$.

The gene expression of the main AF matrix components $b A C A N$ and $b C O L 1 A 1$, inhibitors of matrix degradation $b T I M P-1$ and $b T I M P-2$, matrix degrading enzymes $b M M P-1, b M M P-3$ and $b A D A M T S-4$ and the vascularisation marker $b V E G F$ was also analysed (Fig. 3). While $b A C A N$ expression was not altered in the different groups, $b C O L 1 A 1$ was downregulated in the MSC group when compared to the control group $(p<0.05)$ and in the MSC $(p<0.001)$ and secretome $(p<0.05)$ groups versus the

\section{a}
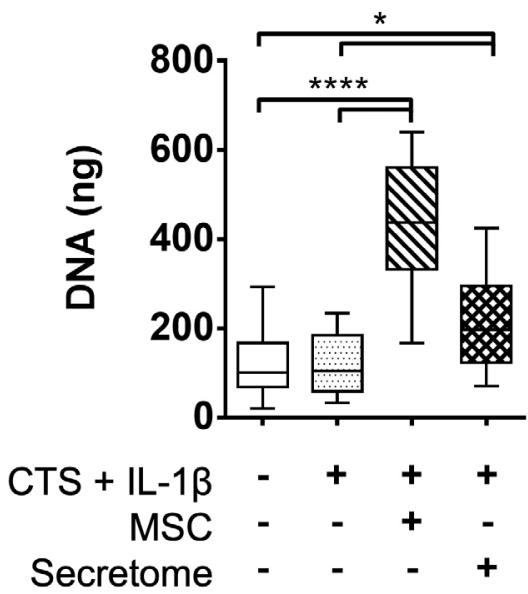

b

\section{Tissue DNA content}

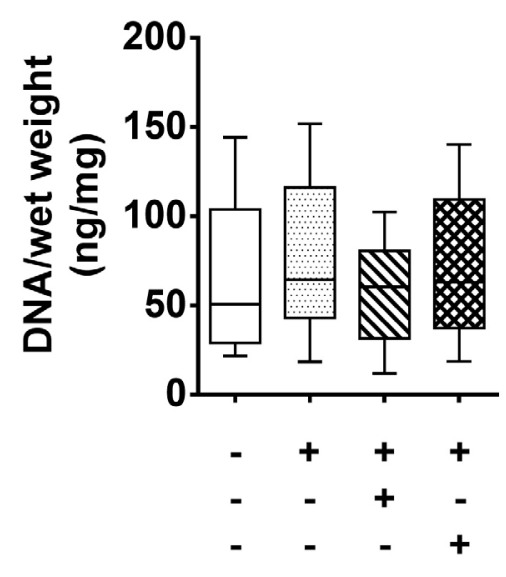

C Collagen
Elastin
sGAG
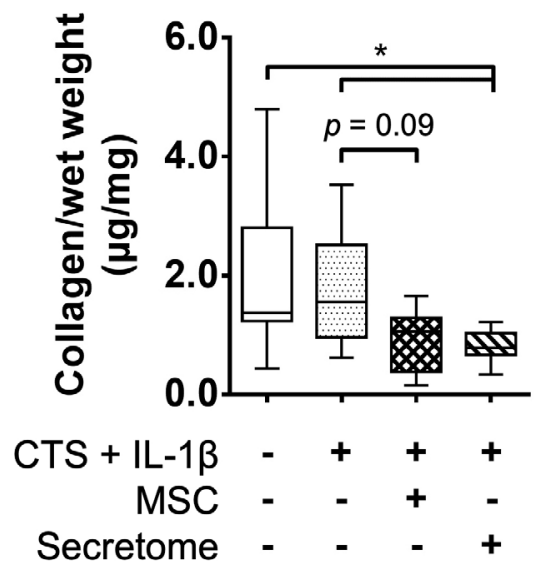

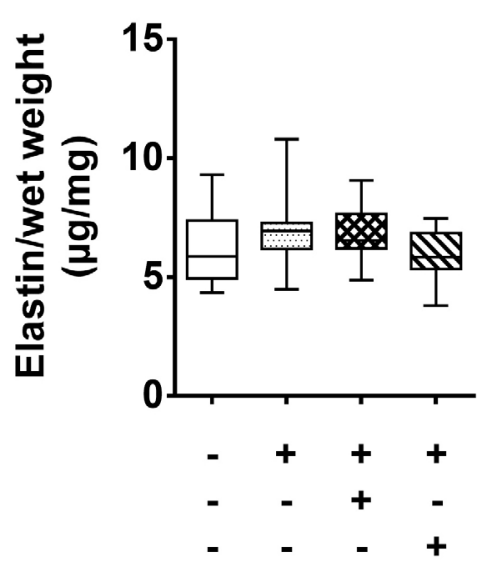

Fig. 4. DNA and protein content of AF-OCs at day 11. (a) Amount of DNA (ng) released to the culture supernatants. (b) DNA content in the AF tissues normalised to wet weight $(\mathrm{ng} / \mathrm{mg})$. (c) Collagen, elastin, and sGAG content in the AF tissues normalised to wet weight ( $\mu \mathrm{g} / \mathrm{mg}) . n=10-18$ (6-12 IVD biological replicates and 1-2 experimental replicates; 3 MSC biological replicates and 3-6 experimental replicates), ${ }^{*} p<0.05,{ }^{* * *} p<0.0001$. 
a
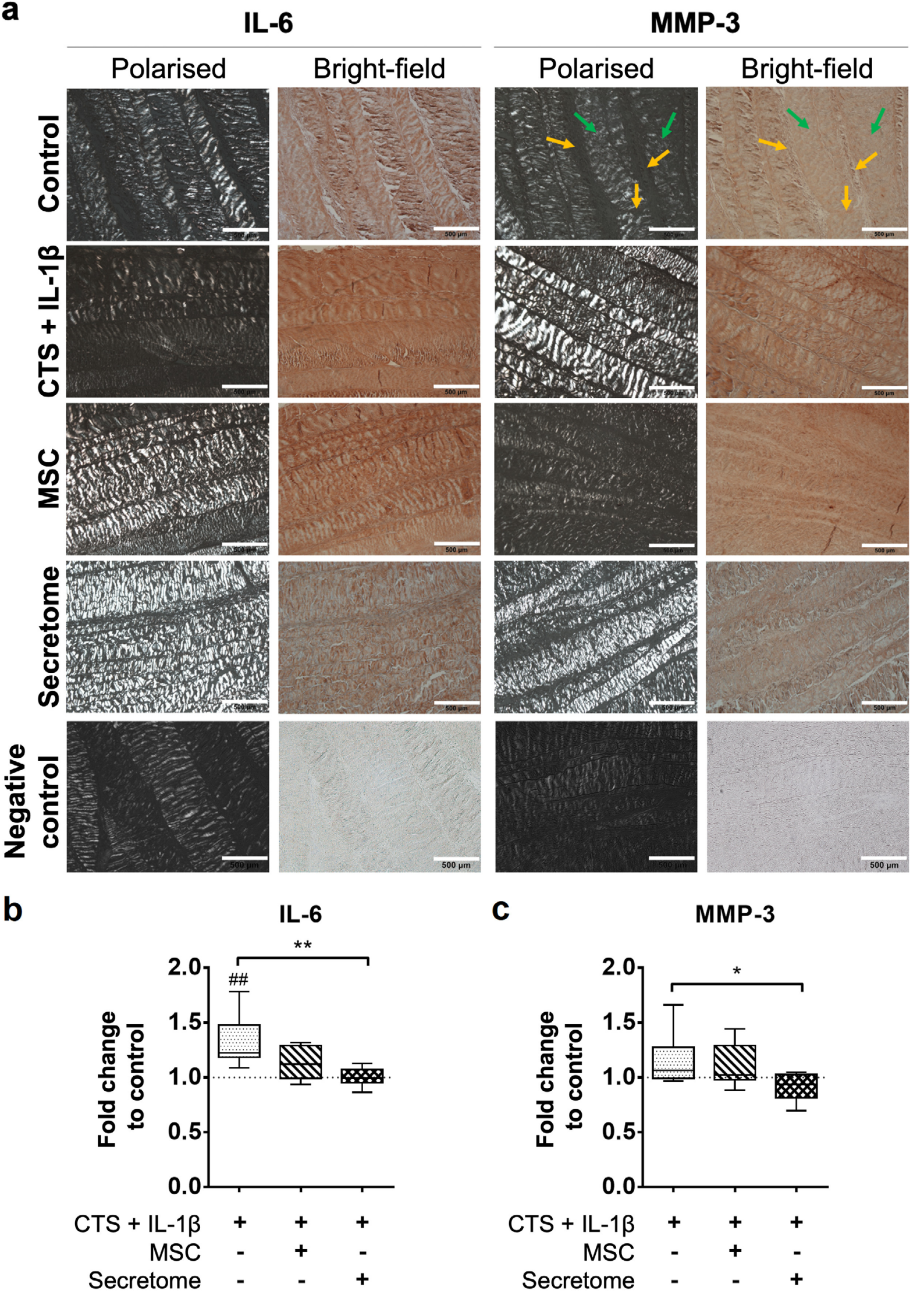

Fig. 5. IL-6 and MMP-3 content of AF-OCs at day 11. (a) Representative images under polarised-light and bright-field of the IL- 6 and MMP-3 distribution within the TLBN (yellow arrows) and the LM (green arrows) of AF-OCs; scale bar: $500 \mu \mathrm{m}$. (b) IL-6 and (c) MMP-3 staining intensity in the TLBN normalised to the LM and to the unstimulated control sample for each experiment. $n=7-10$ (7-10 IVD biological replicates; 3 MSC biological replicates and 2-4 experimental replicates); ${ }^{\# \#} p<0.01$ (versus control, dashed line); ${ }^{*} p<0.05,{ }^{* *} p<0.01$ (between CTS + IL-1 $\beta$ stimulation and treatments). 
CTS + IL-1 $\beta$ group (Fig. 3a). bTIMP-1 was significantly upregulated by CTS + IL- $1 \beta$ stimulation and co-culture with MSCs $(p<0.05$, Fig. 3b). bTIMP-1 and bTIMP-2 were significantly downregulated by the secretome $(p<0.001)$ in comparison to CTS + IL-1 $\beta$ stimulation alone. $b M M P-1, b M M P-3$ and $b A D A M T S-4$ were upregulated in the CTS + IL- $1 \beta$-stimulated and MSC-treated groups when compared to the control group ( $p<0.05$, Fig. 3c) but were downregulated by the combination with the secretome treatment

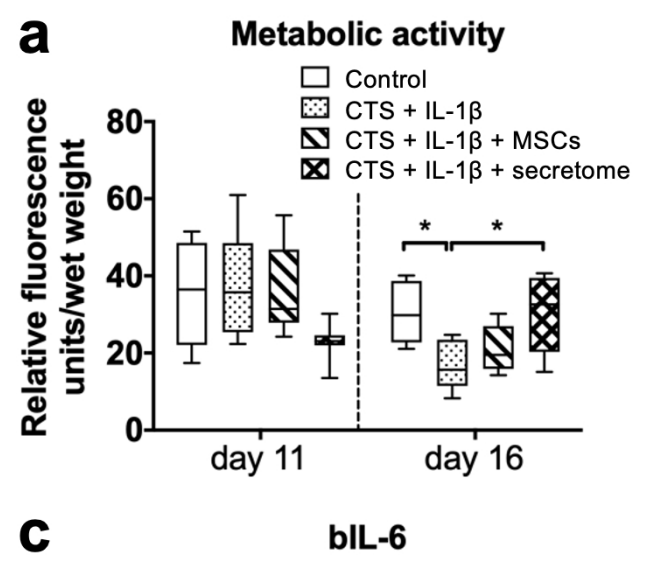

b $\quad \mathrm{PGE}_{2}$
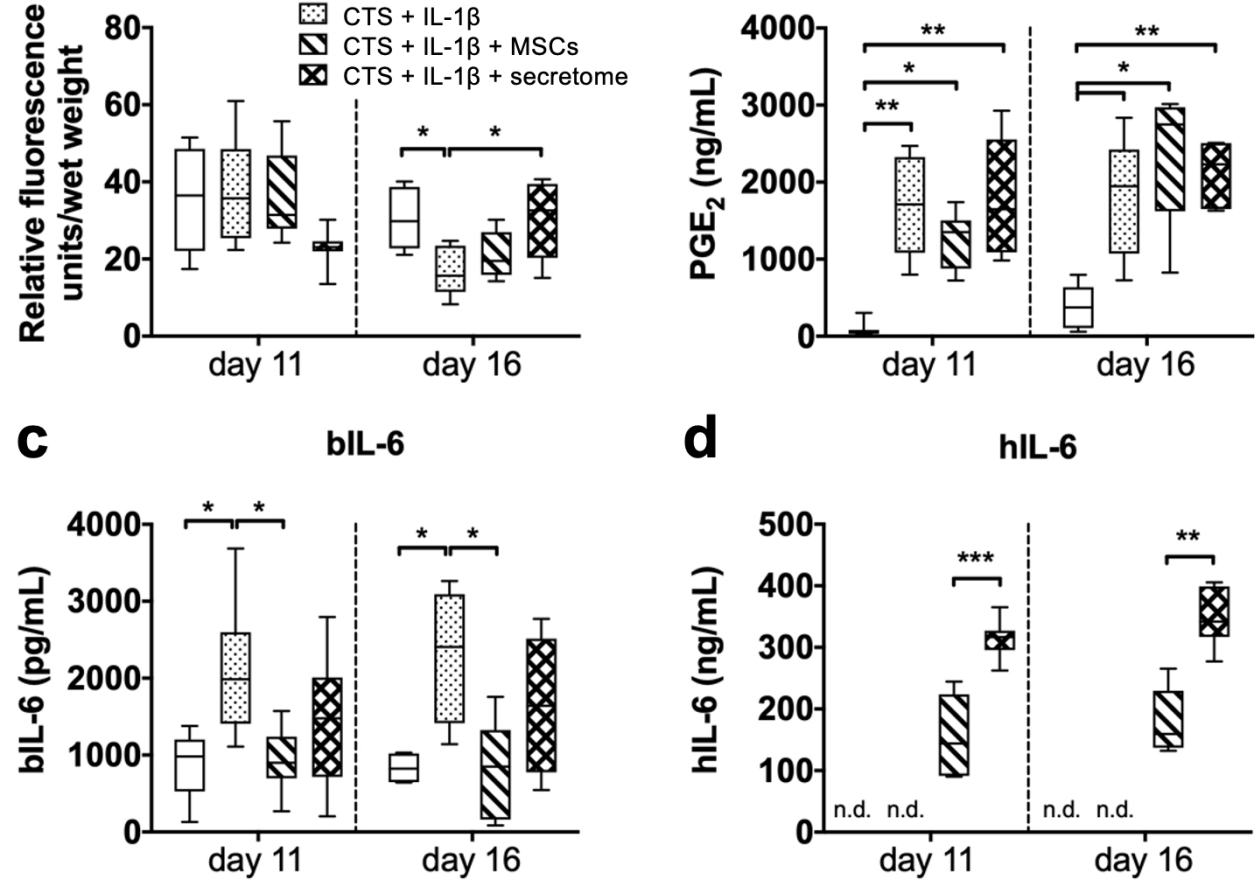

e

hIL-1 $\beta$

f

hIL-1ra
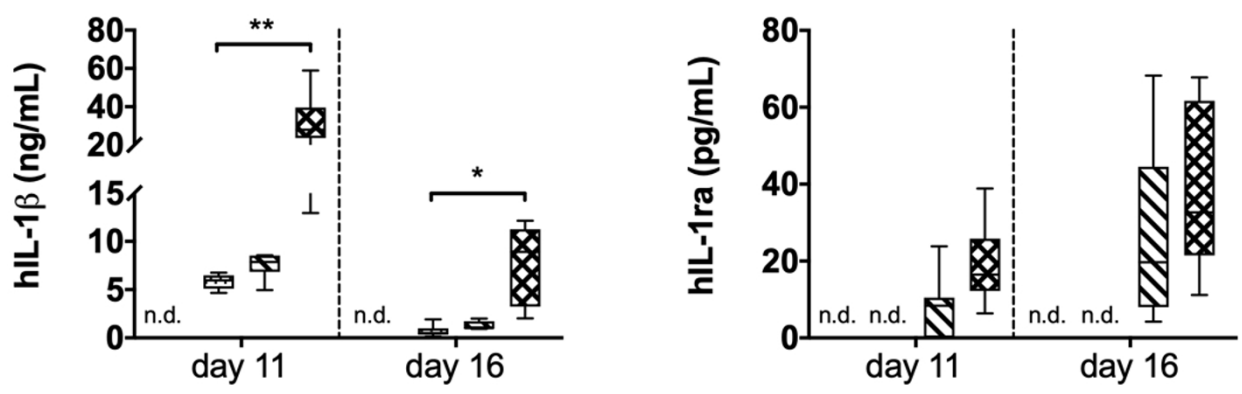

g

hCFH

h

hTIMP-2
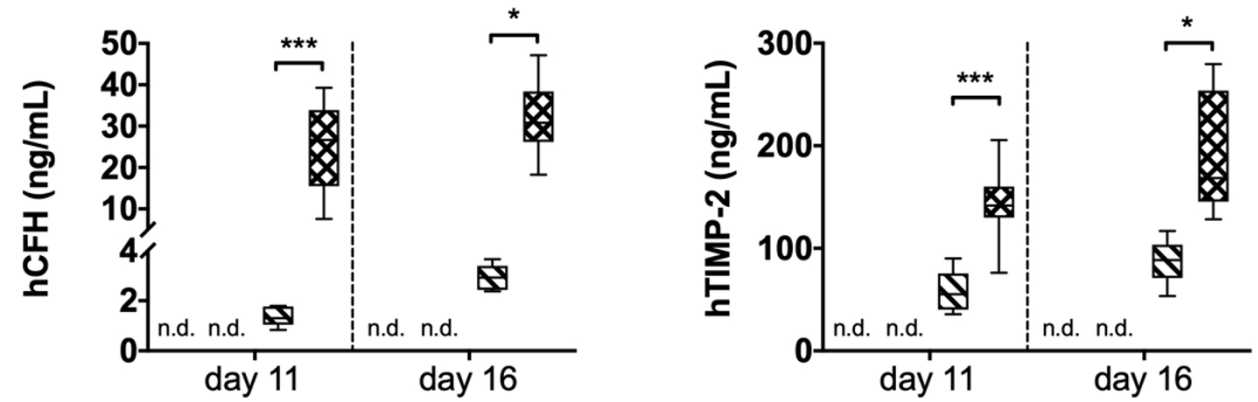

Fig. 6. Cell metabolic activity and protein content of AF-OC supernatants at days 11 and 16. At day 11, $50 \%$ of the medium was exchanged. (a) Mitochondrial metabolic activity of AF-OCs expressed in relative fluorescence units normalised to tissue wet weight. (b) Human/bovine PGE 2 (ng/mL), (c) bIL-6 (pg/mL), (d) hIL-6 (ng/mL), (e) hIL-1 (ng/mL), (f) hIL-1ra (pg/mL), (g) hCFH (ng/mL) and (h) hTIMP-2 (ng/mL) concentrations. $n=6-12$ (6-12 IVD biological replicates; 3 MSC biological replicates and 2-4 experimental replicates), ${ }^{*} p<0.05,{ }^{* *} p<0.01,{ }^{* * *} p<0.001$, n.d.: not detectable. 
compared to CTS + IL-1 $\beta$ ( $p \leq 0.05) . b V E G F$ expression was significantly upregulated with the secretome treatment in contrast to control samples $(p<0.05$, Fig. 3d) but did not present differences compared to CTS + IL-1 $\beta$.

\section{AF matrix remodelling}

Following $4 \mathrm{~d}$ of stimulation, no differences were found in the DNA content released to the culture supernatant between the CTS + IL-1 $\beta$ and control groups (Fig. 4a); whereas the groups treated with MSCs $(p<0.0001)$ or secretome $(p<0.05)$ displayed an increase in the DNA released to the culture supernatant. When the DNA content was quantified in the AF tissue itself, no differences were detected between the groups (Fig. 4b). Collagen, elastin and sGAG matrix content was also quantified in the AF tissue (Fig. 4c). Elastin and sGAG contents were similar under all conditions, whereas collagen content was slightly lower in the MSC-treated group $(p=0.09$, versus CTS + IL-1 $\beta$ alone) and significantly lower in secretome-treated samples $(p<0.05$, in comparison to both the control and CTS + IL-1 $\beta$ groups).

\section{Production of soluble factors}

The distribution of IL-6 and MMP-3 in the AF tissue was assessed by immunohistochemistry at day 11 (Fig. 5). IL-6 and MMP-3 were detected over the entire AF tissue (Fig. 5a). For IL-6, a significantly higher staining intensity was found in the CTS + IL-1 $\beta$ group in comparison to the control group $(p<0.01$, Fig. 5b), which was reduced by secretome treatment $(p<0.01)$. A significantly higher staining intensity was also found for MMP3 on CTS + IL-1 $\beta$ stimulation alone in contrast to the secretome treatment ( $p<0.05$, Fig. 5 c).

The mitochondrial metabolic activity of the cells, as well as PGE ${ }_{2}$, bIL-6, hIL-6, IL-1 $\beta$, IL-1ra, hCFH and hTIMP-2 content in the AF-OC supernatants were quantified at day 11 and 16 (Fig. 6). While at day 11 no significant differences were found in the mitochondrial metabolic activity of the cells (Fig. 6a), at day 16, significantly lower activity was observed in the CTS + IL-1 $\beta$ group $(p<0.05)$, which was recovered in the secretome treatment group $(p<0.05)$. $\mathrm{PGE}_{2}$ production was higher in all stimulated/treated groups versus control samples after 4 (day 11) and 9 (day 16) d of culture $(p<0.05$, Fig. 6b). Interestingly, bIL-6 production was higher after CTS + IL-1 $\beta$ stimulation than in control and co-culture with MSCs at both timepoints ( $p<0.05$, Fig. 6c). hIL-1 $\beta$, hIL-6, hIL1ra, hCFH and hTIMP-2 ELISAs detected specifically human molecules (Fig. 6d-h). Higher hIL-6, hCFH and hTIMP-2 were found in the supernatant of the secretome-treated group in comparison to the release by the MSCs in direct co-culture with the AF-OCs $(p<0.05)$. Slightly higher IL-1ra was detected in the secretome group but without significant differences. $\mathrm{hIL}-1 \beta$ was added to the culture medium of all groups except for the control. At both timepoints of analysis, a slight consumption was observed in the CTS + IL$1 \beta$-stimulated and MSC-treated groups in comparison to the added $10 \mathrm{ng} / \mathrm{mL}$, whereas significantly higher hIL-1 $\beta$ was observed in the secretome-treated group in comparison to CTS + IL-1 $\beta(p<0.05)$. The detected hIL-1 $\beta$ was partially produced by the pre-conditioned MSCs, as well as IL-1ra (Fig. 7).
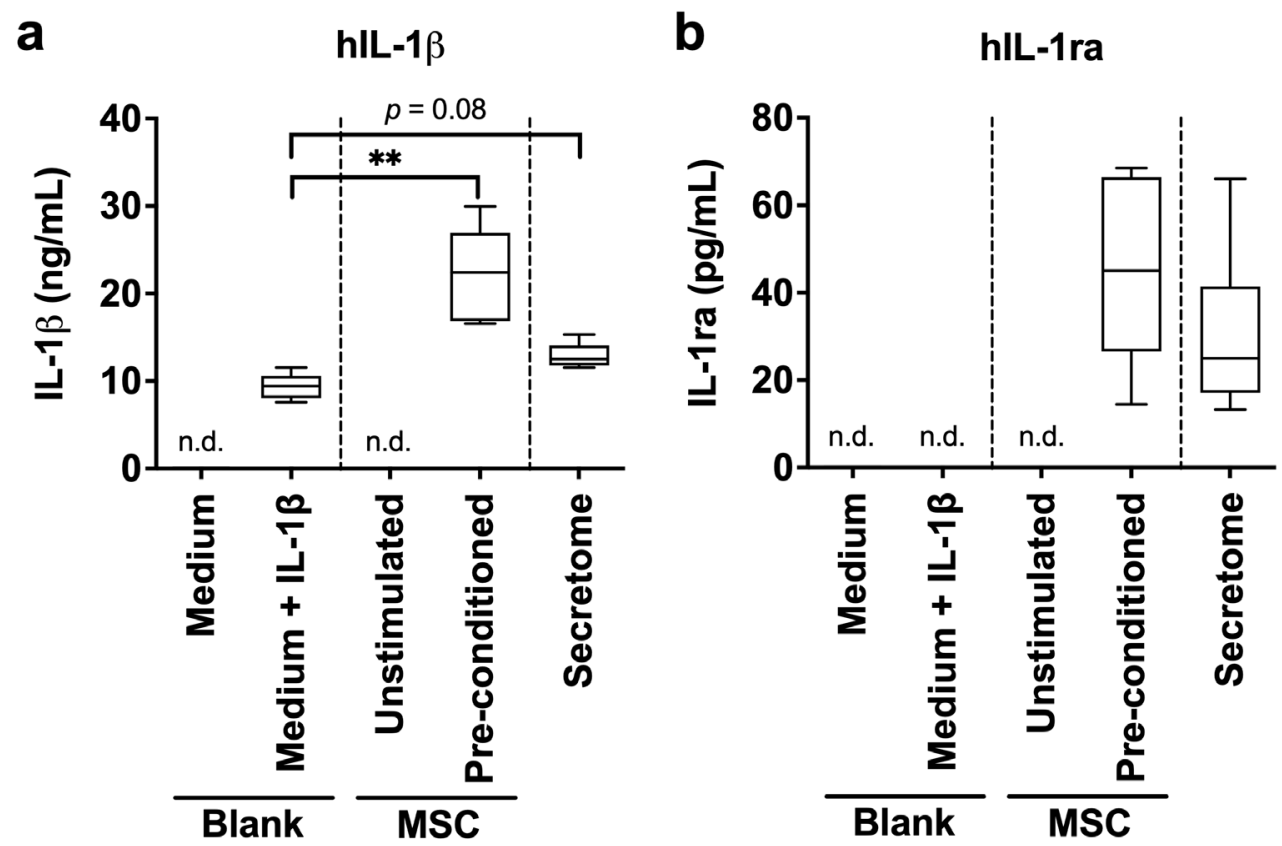

Fig. 7. Protein content of blank basal medium without or with $10 \mathrm{ng} / \mathrm{mL}$ IL-1 $\beta$ supplementation; of human MSC culture supernatants after $48 \mathrm{~h}$ of culture under basal medium and normoxia (unstimulated) or preconditioning (pre-conditioned); and of the secretome solution added to the AF organ cultures (secretome mixed in a $1: 1$ ratio with medium + IL-1 $\beta$ ). (a) Human IL-1 $\beta$ (hIL-1 $\beta, \mathrm{ng} / \mathrm{mL}$ ), and (b) hIL1ra (pg/mL). $n=6$ (3 biological replicates and 2 experimental replicates), n.d. = not detectable, ${ }^{* *} p<0.01$, non-parametric Mann-Whitney test. 


\section{Mechanical properties of AF tissue}

A biomechanical peel test was performed in AF tissue segments after $9 \mathrm{~d}$ of organ culture stimulation/ treatment (Fig. 8). Force-displacement curves were obtained and the mean force along one or more plateau regions was used to calculate the mean annular delamination strength for each sample. No differences between the control and the CTS + IL$1 \beta$ stimulation were observed at this timepoint. Approximately $30 \%$ lower delamination strength was detected in the groups treated with MSCs $(p=0.07)$ and secretome $(p<0.05)$ when compared to the CTS + IL-1 $\beta$ stimulation alone.

\section{Discussion}

The healthy IVD is characterised by a harsh microenvironment, because of low oxygen levels, high osmolarity, nutritional deficits and mechanical loading. These conditions are further exacerbated by degeneration and inflammation (Molinos et al., 2015; Urban, 2002). The proinflammatory/degenerative microenvironment, particularly low oxygen $\left(5 \% \mathrm{O}_{2}\right)$ and low glucose $(1 \mathrm{mmol} / \mathrm{L})$ conditions have been shown to promote stem cell death and inhibit sGAG and collagen production in vitro (Naqvi and Buckley, 2015). In the present study, the proinflammatory and catabolic environment of the IVD was simulated following a previously established ex vivo model of bovine AF rings cultured under low oxygen and glucose supplies, iso-osmotic (400 mOsm) conditions and CTS + IL-1 $\beta$ stimulation (Saggese et al., 2019). However, in the present study, in contrast to Saggese et al. (2019), the AF rings were stimulated with $10 \mathrm{ng} /$

\section{Annular delamination strength}

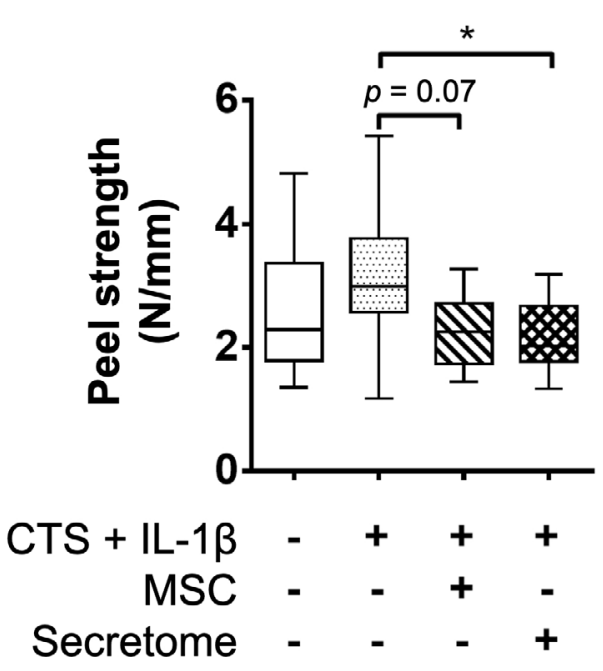

Fig. 8. Annular delamination strength of AF-OCs at day 16. Peel strength as a function of the displacement rate $(\mathrm{N} / \mathrm{mm}) . n=6-12$ (6-12 IVD biological replicates; 3 MSC biological replicates and 2-4 experimental replicates), ${ }^{*} p<0.05$.
$\mathrm{mL}$ instead of $1 \mathrm{ng} / \mathrm{mL}$ IL-1 $\beta$ and a longer stimulation period of up to $9 \mathrm{~d}$ was investigated. The stimulation with $10 \mathrm{ng} / \mathrm{mL}$ IL-1 $\beta$ was previously established for MSCs (Ferreira et al., 2021) and is still in the range of concentrations used by other authors (Le Maitre et al., 2007; Markova et al., 2013; Ponnappan et al., 2011). While IL-1 $\beta$ seemed to be consumed/degraded with time in culture (Fig. 6e in contrast to the initial concentration of the medium + IL-1 $\beta$ in Fig. 7a), the overall expression/production of proinflammatory molecules and matrix-degrading enzymes by AF cells increased after CTS + IL-1 $\beta$ stimulation (as shown in Fig. 2b, 3c, 5, 6b,c). Similarly, the model established by Saggese et al. (2019) was also characterised by an increased production of COX-2, PGE, IL-6 and MMP3. Interestingly, a decrease in mitochondrial metabolic activity was observed in the CTS + IL-1 $\beta$ group after $16 \mathrm{~d}$ of culture (Fig. 6a), which has been previously related with inflammation (Hernández-Aguilera et al., 2013) and AF cell apoptosis (Rannou et al., 2004). But by contrast, cell viability was unaffected, because a similar DNA content was observed for the different groups (Fig. 4b), in agreement with findings from Saggese et al. (2019).

Regarding the expression of complement regulatory proteins that play an important role in the innate immune response, only bCD59 was upregulated after CTS + IL-1 $\beta$ stimulation (Fig. $2 c)$, with no changes observed for $b C D 46$ or $b C D 55$ (important for cell protection against complementmediated lysis). Interestingly, CTS appeared to have a stronger impact on the regulation of these factors than IL-1 $\beta$ (data not shown). By contrast, IL-1 $\beta$ stimulation alone has been previously described to upregulate the expression of these regulators by isolated human articular chondrocytes (Hyc et al., 2003); however, chondrocyte gene expression was investigated only $24 \mathrm{~h}$ after stimulation. Nevertheless, the present study results suggested that, because CD59 is a direct TCC inhibitor, the pathway leading to its formation may play a role in IVD degeneration. This is in agreement with recent findings in human degenerated IVD tissues (Teixeira et al., 2021).

In CTS + IL-1 $\beta$-stimulated AF-OCs, no changes in $b A C A N$ or $b C O L 1 A 1$ gene expression (Fig. 3a) or collagen, elastin or sGAG matrix content (Fig. 4c) were detected in comparison to non-stimulated AF-OCs. Moreover, a slight increase in the annular delamination strength was observed in CTS + IL$1 \beta$-stimulated AF-OCs $(3.1 \pm 1.0 \mathrm{~N} / \mathrm{mm}$, Fig. 7) in comparison to the unstimulated control $(2.6 \pm 1.2 \mathrm{~N} /$ $\mathrm{mm}$ ) after $9 \mathrm{~d}$ of stimulation (but without statistical significance). Interestingly, in the study by Saggese et al. (2019), no changes in the tissue's fibrillin-1 content were detected after $5 \mathrm{~d}$ of CTS + IL- $1 \beta$ stimulation in comparison to untreated controls. However, a decrease in the annular peel strength from $\sim 1.25 \mathrm{~N} /$ $\mathrm{mm}$ in the control group to $\sim 0.8 \mathrm{~N} / \mathrm{mm}$ in the CTS + IL-1 $\beta$ group was detected (Saggese et al., 2019). It appears that, with time in culture, tissues displayed higher delamination strength values in comparison 
to the data previously published by Saggese et al. (2019). This might indicate that changes in other factors which were not the subject of the present study (e.g. versican, collagen type VI) (Melrose et al., 2008) may have contributed to the differences in the peel-force test at the different timepoints. Therefore, to more closely simulate the human physiological conditions and induce matrix breakdown and annular tear, a model using higher strains and complex loading (Heuer et al., 2008) could be used in future investigations.

MSC-based therapies have been investigated for IVD regeneration and back pain treatment because of i) the MSC ability to differentiate in response to the microenvironment and cell-cell interaction into an NP-like phenotype, promoting matrix synthesis (Strassburg et al., 2010), and ii) their anti-inflammatory and immune-modulatory activities (Cunha et al., 2017; Miguélez-Rivera et al., 2018; Teixeira et al., 2018). Clinical trials have shown an increased IVD water content and an improvement of pain and disability in up to 2 years of follow-up (Noriega et al., 2017; Orozco et al., 2011; Pettine et al., 2015; Pettine et al., 2016; Yoshikawa et al., 2010). These therapies have mostly focused on restoring extracellular matrix production (particularly ACAN) and disc biomechanics (Adams and Roughley, 2006; Bendtsen et al., 2016), but still little is known regarding the biological effects of MSC transplantation. Moreover, few studies have addressed/targeted a functional AF repair (Sakai and Grad, 2015). MSCs secrete numerous soluble factors in response to the microenvironmental cues, tuning several mechanisms in neighbour tissues via paracrine signalling (Ferreira et al., 2018). Therefore, the therapeutic potential of MSC secretome has been investigated in the context of several disorders, including degenerative joint diseases (Ferreira et al., 2018). MSC secretome has been suggested to stimulate IVD progenitor cells activity towards repair in degenerated human IVD tissues (Brisby et al., 2013). Nonetheless, the MSC secretome content may be determined by the microenvironment to which the cells are exposed (Ferreira et al., 2018). Therefore, the effect of MSCs versus pre-conditioned MSC secretome was evaluated in the present study.

MSCs were exposed to a low oxygen atmosphere $\left(6 \% \mathrm{O}_{2}\right)$ and proinflammatory stimulus (IL$1 \beta$ medium supplementation), features of the AF-OC microenvironment. The pre-conditioned MSCs displayed upregulated expression of the proinflammatory markers $h I L-6$ and $h I L-8$ and the matrix degrading enzymes $h M M P-1$ and $h M M P-3$ (data not shown). In particular, IL-1 $\beta$-preconditioning has been shown to significantly upregulate the expression of multiple immune-modulating cytokines (e.g. COX-2, IL-6, IL-8) and chemokines (e.g. CCL5), as well as MMPs compared to non-stimulated MSCs (Carrero et al., 2012; Fan et al., 2012; Ferreira et al., 2021). Interestingly, the complement components $h C 3$ and $h C 5$ and regulatory proteins were also shown to be upregulated by the pre-conditioned
MSCs, whereas TCC components $h C 6$ and $h C 9$ were downregulated in comparison to MSCs cultured under atmospheric oxygen conditions and normal expansion medium (data not shown). This indicates a potential to modulate the complement system activation to a certain extent, in agreement with previous findings (Ignatius et al., 2011; Soland et al., 2013). Data from the supernatants of secretometreated AF-OCs (evaluated by ELISA assays without cross-reactivity with bovine molecules) confirmed that preconditioned MSCs produced high concentrations of immune-modulating molecules (Fig. 6), including hIL-6 and hCFH - a first line of complement inhibition (Tu et al., 2010) - as well as hTIMP-2 - a tissue damage mediator. IL-1 $\beta$ and IL-1ra were also produced by pre-conditioned MSCs (Fig. 7). Although IL-1ra has been shown to inhibit IL-1 $\beta$ proinflammatory and catabolic effects when $200 \mu \mathrm{g} /$ $\mathrm{mL}$ were delivered directly onto explants of human degenerate IVDs (Le Maitre et al., 2005, 2007), the concentration produced by pre-conditioned MSCs was very low (in the $\mathrm{pg} / \mathrm{mL}$ range). Therefore, IL-1ra was not expected to have a strong inhibitory effect.

A paracrine immunomodulatory effect of MSC secretome has been described in osteoarthritic cartilage explant cultures (van Buul et al., 2012) and in rat NP/AF cell and macrophage co-cultures (Miguélez-Rivera et al., 2018), and it was confirmed in the present study in the AF-OCs. Molecules produced by the pre-conditioned MSCs contributed to a down-regulation of $b I L-6, b I L-8$ and $b P T G S 2$, as well as of $b C D 46, b C D 55$ and $b C D 59$ by AF cells (Fig. $2 \mathbf{b}, \mathbf{c})$. Interestingly, human/bovine $\mathrm{PGE}_{2}$ production (Fig. 6b) increased with the CTS + IL-1 $\beta$ but was not altered by MSC or secretome treatments even though bPTGS2 was downregulated (Fig. 2b). PGE is highly produced by both MSCs and IVD cells after IL-1 $\beta$ stimulation (Teixeira et al., 2018), in agreement with the present study. By contrast, few effects were observed with MSCs in co-culture when compared to previous findings in which IVD cells displayed a less proinflammatory phenotype in a static model of MSCs and IVD tissue co-cultures (Teixeira et al., 2018). Although the MSC-seeded AF-OC rings were maintained under static conditions for $24 \mathrm{~h}$ after seeding to promote cell adhesion, significantly higher DNA content was found in the supernatant of this group (Fig. 4a), indicating cell detachment. Moreover, the adaptation of the surviving MSCs to the new environment, particularly the dynamic loading, may have affected their anti-inflammatory phenotype and regenerative potential.

In the presence of the MSC secretome, a downregulation of matrix-degrading enzymes and their inhibitors by AF cells (Fig. 3b,c), and a decrease in the bovine/human MMP-3 content in the CTS + IL$1 \beta$-stimulated AF tissue was observed (Fig. 5b). Nevertheless, the secretome also contributed to a weakening of the AF peeling strength, which tended to increase under CTS + IL-1 $\beta$ treatment (Fig. 8). Although no differences were found between the 
MSC-treated group and the control group regarding peeling strength, less collagen was detected at the gene and/or protein level (Fig. 3a,4c, respectively). Because collagen is an important structural protein with an impact on the AF mechanical properties, alterations after secretome treatment will be further investigated in this model and in vivo to better understand its physiological relevance. The study results were in contrast with in vivo studies showing that the MSC secretome may reduce cartilage damage in arthritic mice by reducing ACAN cleavage (Kay et al., 2017) and MMP-13 expression (Chen et al., 2019). Moreover, MSCs-derived exosomes have also been shown to increase ACAN and COL2 and decrease MMP-13 expression by chondrocytes isolated from a murine osteoarthritis model (Liu et al., 2018) and to upregulate ACAN and COL2 by human NP cells (Lu et al., 2017).

Another important aspect to be addressed is angiogenesis/vascularisation, which, while beneficial for tissue repair/regeneration in vascularised tissues, is known to contribute to IVD-degenerationassociated back pain (Binch et al., 2014). Although vascularisation could not be investigated in the stretched AF-OC model, bVEGF was upregulated in AF cells treated with secretome versus control (Fig. 3d). Nevertheless, the secretome did not appear to affect sprouting of human endothelial cells (data not shown). Data did not provide enough evidence on the role of the preconditioned secretome in angiogenesis; however, IL-1 $\beta$ and MSC secretome have been shown to upregulate the expression of pro-angiogenic factors by endothelial cells (Fan et al., 2004; Rosell et al., 2009), but without a functional effect (Fan et al., 2004).

The limitations of the present study include the proinflammatory degenerative microenvironment of the disc, which cannot be completely simulated, and the short investigation time in which the simulation of a therapy in a long-term perspective is not possible. Additionally, the communication between MSCs and cells of the immune system cannot be simulated using this model. Moreover, the tensile strain applied to the system might have contributed to reduced MSC adhesion to the AF rings with time in culture and, therefore, explain why almost no effects were found in the co-culture group.

Overall, the MSC secretome had a potent antiinflammatory effect on the phenotype of AF cells stimulated with CTS + IL-1 $\beta$, which was, therefore, mediated by a paracrine mechanism. It also had an effect on collagen production/degradation, particularly COL1A1, as well as on the AF mechanical properties compared to CTS + IL-1 $\beta$. Future work will investigate the long-term effect of the secretome on the AF matrix.

\section{Conclusions}

AF cells presented a proinflammatory and catabolic phenotype after CTS + IL-1 $\beta$ stimulation for $4 \mathrm{~d}$ but without changes in sGAG, elastin or collagen tissue content. Treatment with the MSC secretome (following preconditioning by $10 \mathrm{ng} / \mathrm{mL}$ IL-1 $\beta$ medium supplementation and culture under $6 \%$ $\mathrm{O}_{2}$ and $8.5 \% \mathrm{CO}_{2}$ for $48 \mathrm{~h}$ ) contributed to a decrease in the inflammatory and catabolic status of AF cells activated by CTS + IL-1 $\beta$ and it also appeared to modulate the activation of cellular complement system regulators. However, the MSC secretome contributed to a decrease in collagen at the gene/ protein level and a reduction in the AF delamination strength in comparison to the CTS + IL- $1 \beta$ stimulation. Ongoing studies with extended culture periods are necessary to evaluate long-term changes in the AF matrix at the protein level and alterations of mechanical properties.

\section{Acknowledgements}

The study was supported by the Ulm University (L.SBN.0157), German Research Foundation (NE_549/6-1), German Spine Foundation (Deutsche Wirbelsäulenstiftung) and German Academic Exchange Service. Andreas Ekkerlein received a dissertation scholarship from the Ulm University and Raquel M. Goncalves was supported by the Alexander von Humboldt Foundation and by Conselho de Reitores das Universidades Portuguesas.

\section{References}

Adams MA, Roughley PJ (2006) What is intervertebral disc degeneration, and what causes it? Spine (Phila Pa 1976) 31: 2151-2161.

Bendtsen M, Bunger C, Colombier P, Le Visage C, Roberts S, Sakai D, Urban JP (2016) Biological challenges for regeneration of the degenerated disc using cellular therapies. Acta Orthop 87: 39-46.

Binch AL, Cole AA, Breakwell LM, Michael AL, Chiverton N, Cross AK, Le Maitre CL (2014) Expression and regulation of neurotrophic and angiogenic factors during human intervertebral disc degeneration. Arthritis Res Ther 16: 416. DOI: 10.1186/s13075-014-0416-1.

Brisby H, Papadimitriou N, Brantsing C, Bergh P, Lindahl A, Barreto Henriksson H (2013) The presence of local mesenchymal progenitor cells in human degenerated intervertebral discs and possibilities to influence these in vitro: a descriptive study in humans. Stem Cells Dev 22: 804-814.

Carrero R, Cerrada I, Lledó E, Dopazo J, GarcíaGarcía F, Rubio MP, Trigueros C, Dorronsoro A, Ruiz-Sauri A, Montero JA, Sepúlveda P (2012) IL1 $\beta$ induces mesenchymal stem cells migration and leucocyte chemotaxis through NF- $\kappa$ B. Stem Cell Rev Rep 8: 905-916.

Chen W, Sun Y, Gu X, Hao Y, Liu X, Lin J, Chen J, Chen S (2019) Conditioned medium of mesenchymal 
stem cells delays osteoarthritis progression in a rat model by protecting subchondral bone, maintaining matrix homeostasis, and enhancing autophagy. J Tissue Eng Regen Med 13: 1618-1628.

Cunha C, Almeida CR, Almeida MI, Silva AM, Molinos M, Lamas S, Pereira CL, Teixeira GQ, Monteiro AT, Santos SG, Gonçalves RM, Barbosa MA (2017) Systemic delivery of bone marrow mesenchymal stem cells for in situ intervertebral disc regeneration. Stem Cells Transl Med 6: 1029-1039.

Dai W, Hale SL, Kloner RA (2007) Role of a paracrine action of mesenchymal stem cells in the improvement of left ventricular function after coronary artery occlusion in rats. Regen Med 2: 63-68.

Fan F, Stoeltzing O, Liu W, McCarty MF, Jung YD, Reinmuth N, Ellis LM (2004) Interleukin-1beta regulates angiopoietin-1 expression in human endothelial cells. Cancer Res 64: 3186-3190.

Fan H, Zhao G, Liu L, Liu F, Gong W, Liu X, Yang L, Wang J, Hou Y (2012) Pre-treatment with IL-1 $\beta$ enhances the efficacy of MSC transplantation in DSSinduced colitis. Cell Mol Immunol 9: 473-481.

Ferreira JR, Teixeira GQ, Neto E, Ribeiro-Machado C, Silva AM, Caldeira J, Leite Pereira C, Bidarra S, Maia AF, Lamghari M, Barbosa MA, Gonçalves RM (2021) IL-1 $\beta$-pre-conditioned mesenchymal stem/ stromal cells' secretome modulates the inflammatory response and aggrecan deposition in intervertebral disc. Eur Cell Mater 41: 431-453.

Ferreira JR, Teixeira GQ, Santos SG, Barbosa MA, Almeida-Porada G, Goncalves RM (2018) Mesenchymal stromal cell secretome: influencing therapeutic potential by cellular preconditioning. Front Immunol 9: 2837. DOI: 10.3389/ fimmu.2018.02837.

Gregory DE, Bae WC, Sah RL, Masuda K (2012) Anular delamination strength of human lumbar intervertebral disc. Eur Spine J 21: 1716-1723.

Grönblad M, Habtemariam A, Virri J, Seitsalo S, Vanharanta H, Guyer RD (2003) Complement membrane attack complexes in pathologic disc tissues. Spine (Phila Pa 1976) 28: 114-118.

Hernández-Aguilera A, Rull A, RodríguezGallego E, Riera-Borrull M, Luciano-Mateo F, Camps J, Menéndez JA, Joven J (2013) Mitochondrial dysfunction: a basic mechanism in inflammationrelated non-communicable diseases and therapeutic opportunities. Mediators Inflamm 2013: 135698. DOI: 10.1155/2013/135698.

Heuer F, Schmidt H, Wilke H-J (2008) The relation between intervertebral disc bulging and annular fiber associated strains for simple and complex loading. J Biomech 41: 1086-1094.

Hyc A, Osiecka-Iwan A, Strzelczyk P, Moskalewski S (2003) Effect of IL-1beta, TNF-alpha and IL-4 on complement regulatory protein mRNA expression in human articular chondrocytes. Int J Mol Med 11: 91-94.

Ignatius A, Schoengraf P, Kreja L, Liedert A, Recknagel S, Kandert S, Brenner RE, Schneider M, Lambris JD, Huber-Lang M (2011) Complement
C3a and C5a modulate osteoclast formation and inflammatory response of osteoblasts in synergism with IL-1ß. J Cell Biochem 112: 2594-2605.

Kay AG, Long G, Tyler G, Stefan A, Broadfoot SJ, Piccinini AM, Middleton J, Kehoe O (2017) Mesenchymal stem cell-conditioned medium reduces disease severity and immune responses in inflammatory arthritis. Sci Rep 7: 18019. DOI: 10.1038/ s41598-017-18144-w.

Krampera M, Cosmi L, Angeli R, Pasini A, Liotta F, Andreini A, Santarlasci V, Mazzinghi B, Pizzolo G, Vinante F, Romagnani P, Maggi E, Romagnani S, Annunziato F (2006) Role for interferon-gamma in the immunomodulatory activity of human bone marrow mesenchymal stem cells. Stem Cells 24: 386-398.

Le Maitre CL, Freemont AJ, Hoyland JA (2005) The role of interleukin- 1 in the pathogenesis of human intervertebral disc degeneration. Arthritis Res Ther 7: R732-745.

Le Maitre CL, Hoyland JA, Freemont AJ (2007) Interleukin-1 receptor antagonist delivered directly and by gene therapy inhibits matrix degradation in the intact degenerate human intervertebral disc: an in situ zymographic and gene therapy study. Arthritis Res Ther 9: R83. DOI: 10.1186/ar2282.

Li W, Ren G, Huang Y, Su J, Han Y, Li J, Chen X, Cao K, Chen Q, Shou P, Zhang L, Yuan Z-R, Roberts AI, Shi S, Le AD, Shi Y (2012) Mesenchymal stem cells: a double-edged sword in regulating immune responses. Cell Death Differ 19: 1505-1513.

Liu Y, Lin L, Zou R, Wen C, Wang Z, Lin F (2018) MSC-derived exosomes promote proliferation and inhibit apoptosis of chondrocytes via lncRNA-KLF3AS1/miR-206/GIT1 axis in osteoarthritis. Cell Cycle 17: 2411-2422.

Livak KJ, Schmittgen TD (2001) Analysis of relative gene expression data using real-time quantitative PCR and the 2(-Delta Delta C(T)) Method. Methods 25: 402-408.

Lu K, Li HY, Yang K, Wu JL, Cai XW, Zhou Y, Li CQ (2017) Exosomes as potential alternatives to stem cell therapy for intervertebral disc degeneration: in-vitro study on exosomes in interaction of nucleus pulposus cells and bone marrow mesenchymal stem cells. Stem Cell Res Ther 8: 108. DOI: 10.1186/s13287017-0563-9.

Markova DZ, Kepler CK, Addya S, Murray HB, Vaccaro AR, Shapiro IM, Anderson DG, Albert TJ, Risbud MV (2013) An organ culture system to model early degenerative changes of the intervertebral disc II: profiling global gene expression changes. Arthritis Res Ther 15: R121. DOI: 10.1186/ar4301.

Melrose J, Smith SM, Appleyard RC, Little CB (2008) Aggrecan, versican and type VI collagen are components of annular translamellar crossbridges in the intervertebral disc. Eur Spine J 17: 314-324.

Miguélez-Rivera L, Pérez-Castrillo S, GonzálezFernández ML, Prieto-Fernández JG, López-González ME, García-Cosamalón J, Villar-Suárez V (2018) Immunomodulation of mesenchymal stem cells in discogenic pain. Spine J 18: 330-342. 
Molinos M, Almeida CR, Caldeira J, Cunha C, Gonçalves RM, Barbosa MA (2015) Inflammation in intervertebral disc degeneration and regeneration. J R Soc Interface 12: 20141191. DOI: 10.1098/ rsif.2014.1191.

Moradi-Lakeh M, Forouzanfar MH, Vollset SE, El Bcheraoui C, Daoud F, Afshin A, Charara R, Khalil I, Higashi H, Abd El Razek MM, Kiadaliri AA, Alam K, Akseer N, Al-Hamad N, Ali R, AlMazroa MA, Alomari MA, Al-Rabeeah AA, Alsharif U, Altirkawi KA, Atique S, Badawi A, Barrero LH, Basulaiman M, Bazargan-Hejazi S, Bedi N, Bensenor IM, Buchbinder R, Danawi H, Dharmaratne SD, Zannad F, Farvid MS, Fereshtehnejad SM, Farzadfar F, Fischer F, Gupta R, Hamadeh RR, Hamidi S, Horino M, Hoy DG, Hsairi M, Husseini A, Javanbakht M, Jonas JB, Kasaeian A, Khan EA, Khubchandani J, Knudsen AK, Kopec JA, Lunevicius R, Abd El Razek HM, Majeed A, Malekzadeh R, Mate K, Mehari A, Meltzer M, Memish ZA, Mirarefin M, Mohammed S, Naheed A, Obermeyer CM, Oh IH, Park EK, Peprah EK, Pourmalek F, Qorbani M, Rafay A, RahimiMovaghar V, Shiri R, Rahman SU, Rai RK, Rana SM, Sepanlou SG, Shaikh MA, Shiue I, Sibai AM, Silva DAS, Singh JA, Skogen JC, Terkawi AS, Ukwaja KN, Westerman R, Yonemoto N, Yoon SJ, Younis MZ, Zaidi Z, Zaki MES, Lim SS, Wang H, Vos T, Naghavi M, Lopez AD, Murray CJL, Mokdad AH (2017) Burden of musculoskeletal disorders in the eastern Mediterranean region, 1990-2013: findings from the global burden of disease study 2013. Ann Rheum Dis 76: 1365-1373.

Murray CJ, Barber RM, Foreman KJ, Abbasoglu Ozgoren A, Abd-Allah F, Abera SF, Aboyans V, Abraham JP, Abubakar I, Abu-Raddad LJ, AbuRmeileh NM, Achoki T, Ackerman IN, Ademi Z, Adou AK, Adsuar JC, Afshin A, Agardh EE, Alam SS, Alasfoor D, Albittar MI, Alegretti MA, Alemu ZA, Alfonso-Cristancho R, Alhabib S, Ali R, Alla F, Allebeck P, Almazroa MA, Alsharif U, Alvarez E, Alvis-Guzman N, Amare AT, Ameh EA, Amini H, Ammar W, Anderson HR, Anderson BO, Antonio CA, Anwari P, Arnlöv J, Arsic Arsenijevic VS, Artaman A, Asghar RJ, Assadi R, Atkins LS, Avila MA, Awuah B, Bachman VF, Badawi A, Bahit MC, Balakrishnan K, Banerjee A, Barker-Collo SL, Barquera S, Barregard L, Barrero LH, Basu A, Basu S, Basulaiman MO, Beardsley J, Bedi N, Beghi E, Bekele T, Bell ML, Benjet C, Bennett DA, Bensenor IM, Benzian H, Bernabé E, Bertozzi-Villa A, Beyene TJ, Bhala N, Bhalla A, Bhutta ZA, Bienhoff K, Bikbov B, Biryukov S, Blore JD, Blosser $\mathrm{CD}$, Blyth FM, Bohensky MA, Bolliger IW, Bora Başara B, Bornstein NM, Bose D, Boufous S, Bourne RR, Boyers LN, Brainin M, Brayne CE, Brazinova A, Breitborde NJ, Brenner H, Briggs AD, Brooks PM, Brown JC, Brugha TS, Buchbinder R, Buckle GC, Budke CM, Bulchis A, Bulloch AG, Campos-Nonato IR, Carabin H, Carapetis JR, Cárdenas R, Carpenter DO, Caso V, Castañeda-Orjuela CA, Castro RE, Catalá-López F, Cavalleri F, Çavlin A, Chadha VK,
Chang JC, Charlson FJ, Chen H, Chen W, Chiang PP, Chimed-Ochir O, Chowdhury R, Christensen H, Christophi CA, Cirillo M, Coates MM, Coffeng LE, Coggeshall MS, Colistro V, Colquhoun SM, Cooke GS, Cooper C, Cooper LT, Coppola LM, Cortinovis M, Criqui MH, Crump JA, Cuevas-Nasu L, Danawi H, Dandona L, Dandona R, Dansereau E, Dargan PI, Davey G, Davis A, Davitoiu DV, Dayama A, De Leo D, Degenhardt L, Del Pozo-Cruz B, Dellavalle RP, Deribe K, Derrett S, Des Jarlais DC, Dessalegn $\mathrm{M}$, Dharmaratne SD, Dherani MK, Diaz-Torné C, Dicker D, Ding EL, Dokova K, Dorsey ER, Driscoll TR, Duan L, Duber HC, Ebel BE, Edmond KM, Elshrek YM, Endres M, Ermakov SP, Erskine HE, Eshrati B, Esteghamati A, Estep K, Faraon EJ, Farzadfar F, Fay DF, Feigin VL, Felson DT, Fereshtehnejad SM, Fernandes JG, Ferrari AJ, Fitzmaurice C, Flaxman $\mathrm{AD}$, Fleming TD, Foigt N, Forouzanfar MH, Fowkes FG, Paleo UF, Franklin RC, Fürst T, Gabbe B, Gaffikin L, Gankpé FG, Geleijnse JM, Gessner BD, Gething P, Gibney KB, Giroud M, Giussani G, Gomez Dantes H, Gona P, González-Medina D, Gosselin RA, Gotay CC, Goto A, Gouda HN, Graetz N, Gugnani HC, Gupta R, Gupta R, Gutiérrez RA, Haagsma J, Hafezi-Nejad N, Hagan H, Halasa YA, Hamadeh RR, Hamavid H, Hammami M, Hancock J, Hankey GJ, Hansen GM, Hao Y, Harb HL, Haro JM, Havmoeller R, Hay SI, Hay RJ, Heredia-Pi IB, Heuton KR, Heydarpour P, Higashi H, Hijar M, Hoek HW, Hoffman HJ, Hosgood HD, Hossain M, Hotez PJ, Hoy DG, Hsairi M, Hu G, Huang C, Huang JJ, Husseini A, Huynh C, Iannarone ML, Iburg KM, Innos K, Inoue M, Islami F, Jacobsen $\mathrm{KH}$, Jarvis DL, Jassal SK, Jee SH, Jeemon P, Jensen $P N$, Jha $V$, Jiang G, Jiang $Y$, Jonas JB, Juel $K$, Kan $H$, Karch A, Karema CK, Karimkhani C, Karthikeyan G, Kassebaum NJ, Kaul A, Kawakami N, Kazanjan K, Kemp AH, Kengne AP, Keren A, Khader YS, Khalifa SE, Khan EA, Khan G, Khang YH, Kieling C, Kim D, Kim S, Kim Y, Kinfu Y, Kinge JM, Kivipelto M, Knibbs LD, Knudsen AK, Kokubo Y, Kosen S, Krishnaswami S, Kuate Defo B, Kucuk Bicer B, Kuipers EJ, Kulkarni C, Kulkarni VS, Kumar GA, Kyu HH, Lai T, Lalloo R, Lallukka T, Lam H, Lan Q, Lansingh VC, Larsson A, Lawrynowicz AE, Leasher JL, Leigh J, Leung R, Levitz CE, Li B, Li Y, Li Y, Lim SS, Lind M, Lipshultz SE, Liu S, Liu Y, Lloyd BK, Lofgren KT, Logroscino G, Looker KJ, Lortet-Tieulent J, Lotufo PA, Lozano R, Lucas RM, Lunevicius R, Lyons RA, Ma S, Macintyre MF, Mackay MT, Majdan M, Malekzadeh R, Marcenes W, Margolis DJ, Margono C, Marzan MB, Masci JR, Mashal MT, Matzopoulos R, Mayosi BM, Mazorodze TT, McGill NW, McGrath JJ, McKee M, McLain A, Meaney PA, Medina C, Mehndiratta MM, Mekonnen W, Melaku YA, Meltzer M, Memish ZA, Mensah GA, Meretoja A, Mhimbira FA, Micha R, Miller TR, Mills EJ, Mitchell PB, Mock CN, Mohamed Ibrahim N, Mohammad KA, Mokdad AH, Mola GL, Monasta L, Montañez Hernandez JC, Montico M, Montine TJ, Mooney MD, Moore AR, Moradi-Lakeh M, Moran AE, Mori R, Moschandreas J, Moturi WN, Moyer 
ML, Mozaffarian D, Msemburi WT, Mueller UO, Mukaigawara M, Mullany EC, Murdoch ME, Murray J, Murthy KS, Naghavi M, Naheed A, Naidoo KS, Naldi L, Nand D, Nangia V, Narayan KM, Nejjari C, Neupane SP, Newton CR, Ng M, Ngalesoni FN, Nguyen G, Nisar MI, Nolte S, Norheim OF, Norman RE, Norrving B, Nyakarahuka L, Oh IH, Ohkubo T, Ohno SL, Olusanya BO, Opio JN, Ortblad K, Ortiz A, Pain AW, Pandian JD, Panelo CI, Papachristou C, Park EK, Park JH, Patten SB, Patton GC, Paul VK, Pavlin BI, Pearce N, Pereira DM, Perez-Padilla R, Perez-Ruiz F, Perico N, Pervaiz A, Pesudovs K, Peterson CB, Petzold M, Phillips MR, Phillips BK, Phillips DE, Piel FB, Plass D, Poenaru D, Polinder S, Pope D, Popova S, Poulton RG, Pourmalek F, Prabhakaran D, Prasad NM, Pullan RL, Qato DM, Quistberg DA, Rafay A, Rahimi K, Rahman SU, Raju M, Rana SM, Razavi H, Reddy KS, Refaat A, Remuzzi G, Resnikoff S, Ribeiro AL, Richardson L, Richardus JH, Roberts DA, RojasRueda D, Ronfani L, Roth GA, Rothenbacher D, Rothstein DH, Rowley JT, Roy N, Ruhago GM, Saeedi MY, Saha S, Sahraian MA, Sampson UK, Sanabria JR, Sandar L, Santos IS, Satpathy M, Sawhney M, Scarborough P, Schneider IJ, Schöttker B, Schumacher AE, Schwebel DC, Scott JG, Seedat S, Sepanlou SG, Serina PT, Servan-Mori EE, Shackelford KA, Shaheen A, Shahraz S, Shamah Levy T, Shangguan S, She J, Sheikhbahaei S, Shi P, Shibuya K, Shinohara Y, Shiri R, Shishani K, Shiue I, Shrime MG, Sigfusdottir ID, Silberberg DH, Simard EP, Sindi S, Singh A, Singh JA, Singh L, Skirbekk V, Slepak EL, Sliwa K, Soneji S, Søreide K, Soshnikov S, Sposato LA, Sreeramareddy CT, Stanaway JD, Stathopoulou V, Stein DJ, Stein MB, Steiner C, Steiner TJ, Stevens A, Stewart A, Stovner LJ, Stroumpoulis K, Sunguya BF, Swaminathan S, Swaroop M, Sykes BL, Tabb KM, Takahashi K, Tandon N, Tanne D, Tanner M, Tavakkoli M, Taylor HR, Te Ao BJ, Tediosi F, Temesgen AM, Templin T, Ten Have M, Tenkorang EY, Terkawi AS, Thomson B, ThorneLyman AL, Thrift AG, Thurston GD, Tillmann T, Tonelli M, Topouzis F, Toyoshima H, Traebert J, Tran BX, Trillini M, Truelsen T, Tsilimbaris M, Tuzcu EM, Uchendu US, Ukwaja KN, Undurraga EA, Uzun SB, Van Brakel WH, Van De Vijver S, van Gool CH, Van Os J, Vasankari TJ, Venketasubramanian N, Violante FS, Vlassov VV, Vollset SE, Wagner GR, Wagner J, Waller SG, Wan X, Wang H, Wang J, Wang L, Warouw TS, Weichenthal S, Weiderpass E, Weintraub RG, Wenzhi W, Werdecker A, Westerman R, Whiteford HA, Wilkinson JD, Williams TN, Wolfe CD, Wolock TM, Woolf AD, Wulf S, Wurtz B, Xu G, Yan LL, Yano $Y$, Ye P, Yentür GK, Yip P, Yonemoto N, Yoon SJ, Younis MZ, Yu C, Zaki ME, Zhao Y, Zheng Y, Zonies D, Zou X, Salomon JA, Lopez AD, Vos T (2015) Global, regional, and national disability-adjusted life years (DALYs) for 306 diseases and injuries and healthy life expectancy (HALE) for 188 countries, 1990-2013: quantifying the epidemiological transition. Lancet 386: 2145-2191.

Naqvi SM, Buckley CT (2015) Extracellular matrix production by nucleus pulposus and bone marrow stem cells in response to altered oxygen and glucose microenvironments. J Anat 227: 757-766.

Neidlinger-Wilke C, Mietsch A, Rinkler C, Wilke HJ, Ignatius A, Urban J (2012) Interactions of environmental conditions and mechanical loads have influence on matrix turnover by nucleus pulposus cells. J Orthop Res 30: 112-121.

Noriega DC, Ardura F, Hernández-Ramajo R, Martín-Ferrero M, Sánchez-Lite I, Toribio B, Alberca M, García V, Moraleda JM, Sánchez A, García-Sancho J (2017) Intervertebral disc repair by allogeneic mesenchymal bone marrow cells: a randomized controlled trial. Transplantation 101: 1945-1951.

Noris M, Remuzzi G (2013) Overview of complement activation and regulation. Semin Nephrol 33: 479-492.

Orozco L, Soler R, Morera C, Alberca M, Sánchez A, García-Sancho J (2011) Intervertebral disc repair by autologous mesenchymal bone marrow cells: a pilot study. Transplantation 92: 822-828.

Parekkadan B, van Poll D, Suganuma K, Carter EA, Berthiaume F, Tilles AW, Yarmush ML (2007) Mesenchymal stem cell-derived molecules reverse fulminant hepatic failure. PLoS One 2: e941. DOI: 10.1371/journal.pone.0000941.

Pereira CL, Teixeira GQ, Ribeiro-Machado C, Caldeira J, Costa M, Figueiredo F, Fernandes R, Aguiar P, Grad S, Barbosa MA, Gonçalves RM (2016) Mesenchymal stem/stromal cells seeded on cartilaginous endplates promote intervertebral disc regeneration through extracellular matrix remodeling. Sci Rep 6: 33836. DOI: 10.1038/srep33836.

Pettine K, Suzuki R, Sand T, Murphy M (2016) Treatment of discogenic back pain with autologous bone marrow concentrate injection with minimum two year follow-up. Int Orthop 40: 135-140.

Pettine KA, Murphy MB, Suzuki RK, Sand TT (2015) Percutaneous injection of autologous bone marrow concentrate cells significantly reduces lumbar discogenic pain through 12 months. Stem Cells 33: 146-156.

Ponnappan RK, Markova DZ, Antonio PJ, Murray HB, Vaccaro AR, Shapiro IM, Anderson DG, Albert TJ, Risbud MV (2011) An organ culture system to model early degenerative changes of the intervertebral disc. Arthritis Res Ther 13: R171. DOI: 10.1186/ar3494.

Rannou F, Lee TS, Zhou RH, Chin J, Lotz JC, Mayoux-Benhamou MA, Barbet JP, Chevrot A, Shyy JY (2004) Intervertebral disc degeneration: the role of the mitochondrial pathway in annulus fibrosus cell apoptosis induced by overload. Am J Pathol 164: 915-924.

Ren G, Zhang L, Zhao X, Xu G, Zhang Y, Roberts AI, Zhao RC, Shi Y (2008) Mesenchymal stem cellmediated immunosuppression occurs via concerted action of chemokines and nitric oxide. Cell Stem Cell 2: 141-150.

Ricklin D, Lambris JD (2013) Complement in immune and inflammatory disorders: pathophysiological mechanisms. J Immunol 190: 3831-3838. 
Risbud MV, Shapiro IM (2014) Role of cytokines in intervertebral disc degeneration: pain and disc content. Nat Rev Rheumatol 10: 44-56.

Roberts S, Evans H, Trivedi J, Menage J (2006) Histology and pathology of the human intervertebral disc. J Bone Joint Surg Am 88 Suppl 2: 10-14.

Rosell A, Arai K, Lok J, He T, Guo S, Navarro M, Montaner J, Katusic ZS, Lo EH (2009) Interleukin$1 \beta$ augments angiogenic responses of murine endothelial progenitor cells in vitro. J Cereb Blood Flow Metab 29: 933-943.

Saggese T, Teixeira GQ, Wade K, Moll L, Ignatius A, Wilke HJ, Goncalves RM, Neidlinger-Wilke C (2019) Georg Schmorl Prize of the German Spine Society (DWG) 2018: Combined inflammatory and mechanical stress weakens the annulus fibrosus: evidences from a loaded bovine AF organ culture. Eur Spine J 28: 922-933.

Sakai D, Andersson GB (2015) Stem cell therapy for intervertebral disc regeneration: obstacles and solutions. Nat Rev Rheumatol 11: 243-256.

Sakai D, Grad S (2015) Advancing the cellular and molecular therapy for intervertebral disc disease. Adv Drug Deliv Rev 84: 159-171.

Sakai D, Nakamura Y, Nakai T, Mishima T, Kato S, Grad S, Alini M, Risbud MV, Chan D, Cheah KS, Yamamura K, Masuda K, Okano H, Ando K, Mochida J (2012) Exhaustion of nucleus pulposus progenitor cells with ageing and degeneration of the intervertebral disc. Nat Commun 3: 1264. DOI: 10.1038/ncomms2226.

Saparov A, Ogay V, Nurgozhin T, Jumabay M, Chen WC (2016) Preconditioning of human mesenchymal stem cells to enhance their regulation of the immune response. Stem Cells Int 2016: 3924858. DOI: 10.1155/2016/3924858.

Soland MA, Bego M, Colletti E, Zanjani ED, St Jeor S, Porada CD, Almeida-Porada G (2013) Mesenchymal stem cells engineered to inhibit complement-mediated damage. PLoS One 8: e60461. DOI: 10.1371/journal.pone.0060461.

Strassburg S, Richardson SM, Freemont AJ, Hoyland JA (2010) Co-culture induces mesenchymal stem cell differentiation and modulation of the degenerate human nucleus pulposus cell phenotype. Regen Med 5: 701-711.

Teixeira GQ, Boldt A, Nagl I, Pereira CL, Benz $\mathrm{K}$, Wilke HJ, Ignatius A, Barbosa MA, Goncalves RM, Neidlinger-Wilke C (2016) A degenerative/ proinflammatory intervertebral disc organ culture: an ex vivo model for anti-inflammatory drug and cell therapy. Tissue Eng Part C Methods 22: 8-19.

Teixeira GQ, Pereira CL, Ferreira JR, Maia AF, Gomez-Lazaro M, Barbosa MA, Neidlinger-Wilke C, Goncalves RM (2018) Immunomodulation of human mesenchymal stem/stromal cells in intervertebral disc degeneration: insights from a proinflammatory/ degenerative ex vivo model. Spine (Phila Pa 1976) 43: E673-E682.
Tu Z, Li Q, Bu H, Lin F (2010) Mesenchymal stem cells inhibit complement activation by secreting factor H. Stem Cells Dev 19: 1803-1809.

Urban JP (2002) The role of the physicochemical environment in determining disc cell behaviour. Biochem Soc Trans 30: 858-864.

van Buul GM, Villafuertes E, Bos PK, Waarsing JH, Kops N, Narcisi R, Weinans H, Verhaar JA, Bernsen MR, van Osch GJ (2012) Mesenchymal stem cells secrete factors that inhibit inflammatory processes in short-term osteoarthritic synovium and cartilage explant culture. Osteoarthritis Cartilage 20: 11861196.

van Koppen A, Joles JA, van Balkom BW, Lim SK, de Kleijn D, Giles RH, Verhaar MC (2012) Human embryonic mesenchymal stem cell-derived conditioned medium rescues kidney function in rats with established chronic kidney disease. PLoS One 7: e38746. DOI: 10.1371/journal.pone.0038746.

Vergroesen PP, Kingma I, Emanuel KS, Hoogendoorn RJ, Welting TJ, van Royen BJ, van Dieën JH, Smit TH (2015) Mechanics and biology in intervertebral disc degeneration: a vicious circle. Osteoarthritis Cartilage 23: 1057-1070.

Wang Q, Rozelle AL, Lepus CM, Scanzello CR, Song JJ, Larsen DM, Crish JF, Bebek G, Ritter SY, Lindstrom TM, Hwang I, Wong HH, Punzi L, Encarnacion A, Shamloo M, Goodman SB, WyssCoray T, Goldring SR, Banda NK, Thurman JM, Gobezie R, Crow MK, Holers VM, Lee DM, Robinson WH (2011) Identification of a central role for complement in osteoarthritis. Nat Med 17: 1674-1679.

Yoshikawa T, Ueda Y, Miyazaki K, Koizumi M, Takakura Y (2010) Disc regeneration therapy using marrow mesenchymal cell transplantation: a report of two case studies. Spine (Phila Pa 1976) 35: E475-480.

Yu J, Schollum ML, Wade KR, Broom ND, Urban JP (2015) ISSLS prize winner: a detailed examination of the elastic network leads to a new understanding of annulus fibrosus organization. Spine (Phila Pa 1976) 40: 1149-1157.

\section{Discussion with Reviewers}

Reviewer 1: Is there not a control missing, i.d. treatment with MSC secretome without priming? Authors: In the present study, we did not focus on the treatment of AF tissues with MSC secretome without priming because we have previously demonstrated that priming with IL-1 $\beta$ strongly affects the MSC secretome, significantly increasing the production of proinflammatory mediators IL-6, IL-8, MCP-1, CCL5/ RANTES and PGE (Ferreira et al., 2021). This study also showed that the secretome produced by primed MSCs downregulates bovine IVD gene expression of proinflammatory cytokines IL-6 and IL-8 and matrix degrading enzyme MMP-1, while MMP-3 and TIMP2 are upregulated after $48 \mathrm{~h}$ of treatment. Moreover, 
literature data have shown that MSC priming improves their paracrine immunomodulatory effect and capacity to improve tissue repair/regeneration across the wide range of tissues and pathological conditions, including articular cartilage and IVD degeneration (Ferreira et al., 2018). Therefore, we opted to further investigate the effect of the primed MSC secretome on the proinflammatory/degenerative AF-OC model.

Reviewer 2: If there were no significant changes in the annular delamination strength test following CTS + secretome treatment when compared to controls, how does this contribute to further disc degeneration? Authors: The MSC secretome modulated the proinflammatory response of AF cells but also influenced the AF collagen content and mechanical properties of the AF tissue stimulated by CTS + IL$1 \beta$ conditions (Fig. 8). Although no differences were found between the secretome-treated group and the control group regarding peeling strength, less collagen was detected at the protein level (Fig. 4c). Therefore, we hypothesised that the decreased collagen content may be a hint for a weakening of the AF mechanical properties. Nevertheless, the peel-force test measures the strength required (at a constant velocity) for the detachment of adjacent AF lamellae through the TLBN, mostly composed of elastin and fibrillin. Therefore, changes in collagen content may not influence the test. Given this, further investigations of the effect of MSC secretome on matrix turnover and disc degeneration will be necessary.

Editor's note: The Scientific Editor responsible for this paper was Sibylle Grad. 